\title{
Bir Metal Fabrikası İçin İş Çizelgeleme Yazılımı Hazırlanması
}

\author{
Tuğçe KAÇAR ${ }^{1}$, Mehmet Onur OLGUN ${ }^{2 *}$ \\ Geliş / Received: 09/07/2019 \\ Revize / Revised: 20/05/2020 \\ Kabul / Accepted: 21/05/2020

\section{$\overline{\mathbf{O Z Z}}$}

Firmaların günümüz rekabet ortamlarında devamlılığını sürdürebilmeleri için ürettikleri ürün veya hizmeti daha kaliteli ve daha ucuza sunmaları gerekmektedir. Sürekli gelişen üretim teknikleri ve her geçen gün büyüyen üretim sistemleri sebebiyle üretim faaliyetleri karmaşıklaşmış, basit üretim faaliyetlerinin kontrolü zorlaşmıştır. Üretim planlama faaliyetleri, üretilecek olan ürünün belirlenmesi, gerekli olan donanımların saptanması, ürünlerin istenilen sürede ve istenilen miktarda üretimini sağlayacak programlama ve çizelgeleme çalışmalarını kapsamaktadır.

Üretim çizelgeleme problemleri belirli sayıdaki işlerin belirli sayıdaki makineye hangi sıra ile yüklenmesi gerektiğinin belirlenmesidir. Üretim çizelgeleme problemlerinin çözümünde farklı yöntemler mevcuttur. Tüm yöntemlerin ortak amacı mevcut tüm siparişlerin tamamlanması için gerekli toplam akış zamanını en küçüklemektir. Bu yöntemlerin çözümleri Gantt diyagramları ile yapılır.

$\mathrm{Bu}$ çalışmada üretim çizelgeleme ile ilgili genel bilgiler verilmiştir. Geliştirilen iş çizelgeleme paket programı yazılımı tanıtılmış ve örnek olması amacıyla metal üretimi yapan bir fabrikada uygulanmıştır. Program yazılımında C\# dili, veri tabanı olarak Access kullanılmıştır. Programın amacı çizelgeleme işlemlerini kolaylaştırarak firmaların farklı yöntemlerle oluşturulan çizelgeleri de inceleyebilmelerini ve kıyaslama yaparak en doğru yöntemi kullanmalarını sağlamaktır.

Anahtar Kelimeler- Üretim planlama, Üretim çizelgeleme, Gantt şeması, Programlama, C\# yazılımı

\footnotetext{
1 İletişim: tugceekacar@gmail.com (https://orcid.org/0000-0002-3335-314X)

Endüstri Mühendisliği Bölümü, Süleyman Demirel Üniversitesi

2*Sorumlu yazar iletişim: onurolgun@sdu.edu.tr (https://orcid.org/0000-0002-7568-3235)

Endüstri Mühendisliği Bölümü, Süleyman Demirel Üniversitesi
} 


\title{
Preperation of Business Scheduling Software for a Metal Factory
}

\begin{abstract}
In order to maintain continuity in today's competitive environment, companies provide products and services that are produced with higher quality and cheaper. Continuous production techniques and production systems technology production plant has become more complex and control of simple production activities has become more difficult. The production planning option is capable of planning and planning the production of the production, available, identified and required equipment, wherever and wherever we want.

Production scheduling problems determine the order in which a certain number of jobs must be loaded on a certain number of machines. There are different methods for solving production scheduling problems. The common goal of all methods is to minimize the total flow time required to complete all existing orders. Solutions of these methods are made with Gantt diagrams.

In this study, general information about production scheduling is given. The developed business scheduling software was introduced and implemented in a metal manufacturing factory for example. $\mathrm{C}$ \# language is used in the program software and Access is used as database. The aim of the program is to facilitate the scheduling process so that the firms can examine the charts created by different methods and make the comparison and use the most accurate method.
\end{abstract}




\section{GIRIŞ}

Üretim yapan bir fabrikanın temel amacı, müşteri taleplerini zamanında karşılayabilmektir. Bu amaç doğrultusunda mevcut stok miktarları, makine ve çalışan kapasiteleri, makine bakım planları ve çalışan verimlilikleri gibi değerler planlanmalı ve sürekli gelişen teknoloji ile rekabet gücünü koruyabilmek için kontrol altında tutulmalıdır. Üretim planlama ve çizelgeleme problemleri bu noktada ortaya çıkmıştır.

Üretim çizelgeleme, herhangi bir ürünün üretilmesi için gerekli olan hammaddenin ve yarı mamullerin mevcut olan tek ya da çok sayıdaki makinelerde ne zaman ve hangi sırada işleneceğinin belirlenmesidir. Üretim çizelgeleme problemleri, üretim tiplerine göre değişiklik göstermektedir. Çizelgeleme problemleri kademe sayılarına göre dört farklı başlık altında incelenir. Bu başlıklar;

-Tek kademeli, tek makineli problemler,

-Tek kademeli, paralel makineli problemler,

-Çok kademeli problemler ve

-Atölye tipli problemlerdir.

İş çizelgeleme yapılırken birçok öncelik kuralı bulunmaktadır. Bunlardan bazıları:

- İlk gelen ilk hizmet alır (İGİHA),

- Teslim tarihi en yakın olan ilk hizmet alır (TTEY),

- Kalan boşluk süresi en kısa olan ilk hizmet alır (KBSEK),

- İşlem süresi en uzun olan ilk hizmet alır (İSEU),

- İşlem süresi en kısa olan ilk hizmet alır (İSEK),

- $\quad$ Kritik oran $(\mathrm{KO})$,

- Öncelikli müşterinin siparişi ilk hizmet alır (ÖMS),

- $\quad$ Rassal hizmet örnek olarak verilebilir (RH).

Bu çalışma kapsamında üretim çizelgeleme paket program yazılımı yapılmış ve örnek olarak bir metal fabrikasında uygulanmıştır.

Proje kapsamında ilk gelen ilk hizmet alır, teslim tarihi en yakın olan ilk hizmet alır, işlem süresi en uzun olan ilk hizmet alır ve işlem süresi en kısa olan ilk hizmet alır olmak üzere dört farklı öncelik kuralı seçilmiştir.

Projenin uygulama aşamasında metal sektöründen faaliyet gösteren bir firma ile çalışılmıştır. Firma kepenk, pergole gibi ürünler üreten firmalara yarı mamul tedarik etmektedir. Kepenk üretimi için gerekli olan yarı mamullerin akış şemaları kepenk akış şeması içerisinde ayrıntılı olarak verilmiştir.

Çalışma altı ana bölümden oluşmaktadır. Birinci bölümde makale içeriği hakkında bilgi verilmiştir. İkinci bölümde daha önce üretim çizelgeleme ile ilgili yapılmış olan çalışmalar incelenmiş ve bazı çalışmalar özetlenmiştir. Üçüncü bölümde makalenin ana konusu olan üretim çizelgeleme yöntemleri ile ilgili genel bilgiler verilmiştir. Dördüncü bölümde çalışmanın uygulandığı fabrika tanıtılmış ve yazılan program hakkında bilgiler sunulmuştur. Beşinci bölümde metal sektöründe yer alan ve esnek atölye tipli üretimin gerçekleştiği bir işletmede işlerin ve bu işlere ait operasyonların makinelere hangi sırayla atanması gerektiği ve atanan son siparişin tamamlanma zamanın en düşük olduğu atamanın bulunarak siparişlerin makinelerde hangi sırayla işlenmesi 
gerektiğinin bulunması sağlanmıştır. Altıncı bölümde ise çalışmanın kazanımları ve programın uygulanması ile elde edilen sonuçlar paylaşılmıştır.

\section{BİLIMMSEL YAZIN TARAMASI}

Bu çalışma kapsamında çizelgeleme ile ilgili bilimsel makale ve çalışmalar incelenmiştir. Çizelgeleme yöntemleri sınıflandırılmış, uygulaması yapılan atölye tipi çizelgeleme yöntemi hakkında yapılan çalışmalar özetlenmiştir.

Aydemir [1], atölye tipi çizelgeleme problemlerindeki öncelik kurallarını kullanarak genetik algoritma yaklaşımı ile ilgili bir simülasyon çalışması yapmıştır. Çalışmasında iş akış planlarında yer alan işlemlerin, son iş bitene kadar geçen süreyi en küçükleyecek bir yazılım geliştirmiştir. Geliştirilen yazılımı kalorifer kazanı imalatı yapan bir işletme için uygulamıştır.

Sarıkaya [2], otomotiv sektöründeki bir yan sanayi işletmesinin üretim hattını inceleyerek üretim merkezleri üzerinde simülasyon modellerini araç olarak kullanmış ve bu konu üzerinden analizler yapmıştır. Elde ettiği sonuçları neticesinde işlem sıralarına bağımlı olan ve hazırlık süreleri nedeniyle zor ve karmaşık yapılı çizelgeleme problemlerini incelemiştir.

Candan [3], çalışmasında esnek üretim sistemlerinde çizelgeleme problemleri için toplam akış zamanını en aza indirgeyecek etkenlerin belirlenmesi üzerine bir çalışma yapmıştır.

Altındaş [4], yaptığı çalışmada üretim çizelgeleme süreçlerindeki problemlerin tanımlaması, çözüm yöntemlerinin araştırılması, hangi sınıflandırmaya ait olduğunun belirlenmesi, uygun olan çözüm yönteminin seçilmesi üzerinde durmuştur. Çalışmasının uygulama bölümünde mobilya sektöründen bir firma ile çalışmış, Lekin paket programını kullanarak bir çözüm elde etmiştir.

Doğan [5], hazırlık sürelerinin olduğu sıralamaya bağlı permütasyonlu ve çok amaçlı akış tipi üretim problemlerini ele alarak bir çalışma gerçekleştirmiştir. Ele aldığı problemlerin çözümü için problemin çok amaçlı doğası ve çok amaçlı permütasyonlu akış tipi olmak üzere iki yaklaşımı önermiştir.

Eren ve Güner [6], tek ve paralel makineli üretim sistemlerinde çok ölçütlü çizelgeleme problemleri üzerine bir çalışma yapmıştır. Çalışmalarında paralel makineli üretim sistemlerinin de tek makineli üretim sistemlerinde olduğu gibi tek bir işleme ihtiyaç duyduklarını belirtmişlerdir. Ancak bu üretim sistemlerinde gelen işlerin m paralel işleyicinin herhangi birinde yapılabileceğini söylemişler ve çalışma kapsamına dahil etmişlerdir.

Esnek atölye tipi çizelgeleme problemleri ile ilgili yapılan çalışmalar incelendiğinde bu problemin ilk olarak 1990’lı yıllarda Brucker ve Schile tarafından ele alındığı görülmüştür. Brucker ve Schile [7] çalışmasında, çok amaçlı makineler ile kurulmuş fabrika ortamlarında iki işin çizelgelenmesi için polinomsal grafik algoritması geliştirmişlerdir. Bu algoritmadaki amaç en son işin tamamlanma zamanını en küçükleyerek çizelge modelini oluşturmaktır. Ancak geliştirdikleri bu algoritma üç ve daha fazla sayıda iş içeren modeller için etkili olmamıştır. Esnek atölye tipi ile ilgili yapılan bu çalışmadan sonra problemlerin çözüm performansını arttırabilmek için melez yöntemler geliştirilmeye başlanmıştır.

Esnek atölye tipi çizelgeleme problemlerinin çözümlerinde işlerin sıralanması ve ilgili makinelere atanması iki önemli problem olarak ortaya çıkmıştır. Bu problemlerin çözümü iki yaklaşımla sınıflandırılmıştır. Bunlar; hiyerarşik yaklaşım ve bütünleşik yaklaşımdır. Hiyerarşik yaklaşımda ana problem alt problemlere bölünerek çözüme gidilmektedir. Bu yaklaşımdan dolayı problem kolaylaştırılmaktadır. Pauli [8] ve Brandirmarte [9] çalışmaları için bu yaklaşımı kullanmıştır. Bütünleşik yaklaşımda ise en iyi sonucu elde edebilmek için çözüm zorlaştırılmaktadır. Gambardella ve Mastrolilli [10], Bagheri ve diğerleri [11] çalışmalarında bu yaklaşımı konu almışlardır.

Pauli [8], yaptığı çalışmada esnek üretim sistemlerindeki problemlerden bahsetmiştir. Bu çalışmayı yaparken tüm işler içerisindeki son işin tamamlanma zamanını en küçüklemeyi amaçlamıştır. 
Brandimarte [9], hiyerarşik yaklaşım modeli kapsamında dağıtım kurallarını kullanarak problem çözümler için tabu arama yöntemini geliştirmiştir. Optimum çözümü bulunduran iterasyon sayısından sonra yeni bir çizelgeleme modeli oluşturmak için her işlem bir makineden diğer makineye aktarılmıştır. Brandimarte kullandığı yöntem için tek yollu bilgi akışlı hiyerarşik yaklaşımlardan farklı olarak iki yollu bilgi akışı sağladığını söylemiştir. Bu nedenle bu yöntemin farklı amaçlar için de uygulanabileceğini belirtmiştir.

Gambardella ve Mastrolili [10], bütünleşik yaklaşım ile problemleri çözebilmek için meta-sezgisel en iyileme yöntemlerini kullanmışlardır. Bu yöntem ile ilgili komşuluk fonksiyonları önermişlerdir. Önerdikleri bu fonksiyon ile diğer sezgisel çalışmalara göre daha iyi sonuçlara ulaşmışlardır.

Bagheri ve diğerleri [11], çalıştıkları esnek atölye tipli çizelgeleme problemlerinde son işin tamamlanma zamanının en küçüklenmesi için yapay bağışıklık tabanı ile bütünleşik bir algoritma ortaya koymuşlardır. Bu algoritmanın başlangıç çözümünde farklı stratejiler kullanılmıştır. Yeni bireyler oluşturmak amacı ile farklı mutasyon operatörleri tanımlamışlardır. Oluşturdukları algoritmaları literatürdeki problem setleri ile çözmüş ve doğru sonuçlar verdiğini göstermişlerdir.

Kacem ve diğerleri [12], atölye tipli çizelgeleme problemlerinin çözümüne iki yeni yaklaşım getirmişlerdir. Bunlar kısmi esneklik ve tam esnekliktir. Esnek atölye tipli çizelgeleme problemlerinde bu yaklaşımlar kullanılmıştır. Kısmi esnek atölye tipli çizelgeleme problemlerinde her işlem özdeş ya da özdeş olmayan makineler alt kümesinde makine özelliklerine göre aynı veya farklı zamanlarda işlem görebilmektedir. Tam esnek atölye tipli çizelgeleme problemleri ise işlemlerin tüm makinelere makine özelliklerine göre aynı veya farklı zamanlarda işlem görebilmektedir. Tam esnek atölye tipli çizelgeleme problemlerinde işlemler, herhangi bir makineye rastgele atanabilmektedir. Fakat kısmi esnek atölye tipli çizelgeleme problemlerinde böyle bir atama mümkün değildir.

\section{YÖNTEM}

Programlama dillerinden C\# kullanılmış olup veri tabanı programı olarak Access seçilmiştir. Üretim planlama bölümlerinde sıklıkla kullanılan üretim çizelgeleme yöntemlerinden akış tipi makine çizelgeleme seçilmiştir. $\mathrm{Bu}$ bölümde üretim çizelgeleme ile ilgili konulardan bahsedilecektir. Üretim çizelgeleme problemlerinin genel sınıflandırılması ve çizelgelemede kullanılan öncelik kuralları ile ilgili gerekli bilgilere ve açıklamalara yer verilecektir.

\section{A. Üretim Çizelgeleme}

Üretim çizelgeleme problemleri için tek tip bir sınıflandırma yapılamaz. Bu nedenle çeşitli sınıflandırma şekilleri de anlatılacaktır. Üretim çizelgeleme problemlerinin zorluğunun ve karmaşıklığının nasıl değiştiği ve zorluğu yüksek problemlerde kullanılan öncelik yöntemleri özetlenecektir.

Çizelgeleme kuramı; sağlık, spor, bilişim, lojistik gibi değişik sektörlerdeki sıralama problemlerinde uygulanabilmektedir. Pinedo [13], çalışmasında üretim çizelgeleme faaliyetlerinin; üretim merkezlerine, kısıtlı kaynakların ve zamanın dikkate alınarak hangi sırayla atanmasına karar vermede yardımcı bir süreç olarak birçok ülkede düzenli olarak kullanıldığından bahsetmiştir. Büyüksünetçi [14], ise üretim çizelgeleme, belirli bir hedef doğrultusunda belirli bir zaman içerisinde ve belirli kısıtlar altında işlerin bitirilebilmesi için sınırlı olan kaynaklara atanması süreci olarak tanımlamıştır.

Üretim çizelgeleme ve sıralama sürecinde öncelikle elimizde hangi üretim merkezlerinden ne kadar bulunduğunun belirlenmesi gerekmektedir. Her işlemin bu üretim merkezlerinden ne kadarına ihtiyaç duyduğunu, bu işlemlerin tamamlanması için üretim merkezlerinde ne kadar birim işlem süresinin gerektiğini ve bu işleme en erken veya en geç ne zaman başlanabileceği gibi bilgilerin bilinmesi ve kayıt altında tutulması gerekmektedir. Ayrıca siparişler arasındaki öncelik ilişkileri gibi teknolojik kısıtların da bilinmesi gerekmektedir.

Çizelgeleme, firmaların karar verme işlemlerini kolaylaştırmaktadır. Üretim sektörlerinde makine yüklemelerinin nasıl olması gerektiği, hangi siparişin daha önce yapılması gerektiği gibi konularda öne çıkarken hizmet sektöründe örneğin otogarlar için otobüslerin giriş çıkışlarını kontrol altında tutulabilmektedir. 
Çizelgelemelerin zaman ekseninde gösterimi için Gantt diyagramlarından faydalanılır. Gantt diyagramı işlem bazlı ve makine bazlı olmak üzere ikiye ayrılır. İşlem bazlı Gantt diyagramında makineler yerine işlere odaklanır. Herhangi bir ürünün üretim aşamasındaki her işlemin üretim merkezlerinde ne kadar süre harcadıkları, üretim merkezleri arasındaki izledikleri rota ve hangi üretim merkezinde ne zaman işlem görmeye başlayıp tamamlandığı incelenmektedir. Makine bazlı Gantt diyagramında ise işlemlerin yanı sıra makinelere odaklanılır. X ekseninde zaman, Y ekseninde ise makineler bulunur. Zamana göre makine yükleme işlemi gerçekleştirilir. Bu çalışmada İşlem bazlı Gantt diyagramı ile çizelgeleme metodu üzerinde çalışılmıştır. İşlem bazlı ve makine bazlı Gantt diyagramı çizelgelemeleri daha iyi anlaşılması için temsili olarak Şekil 1 ve Şekil 2'de gösterilmiştir.

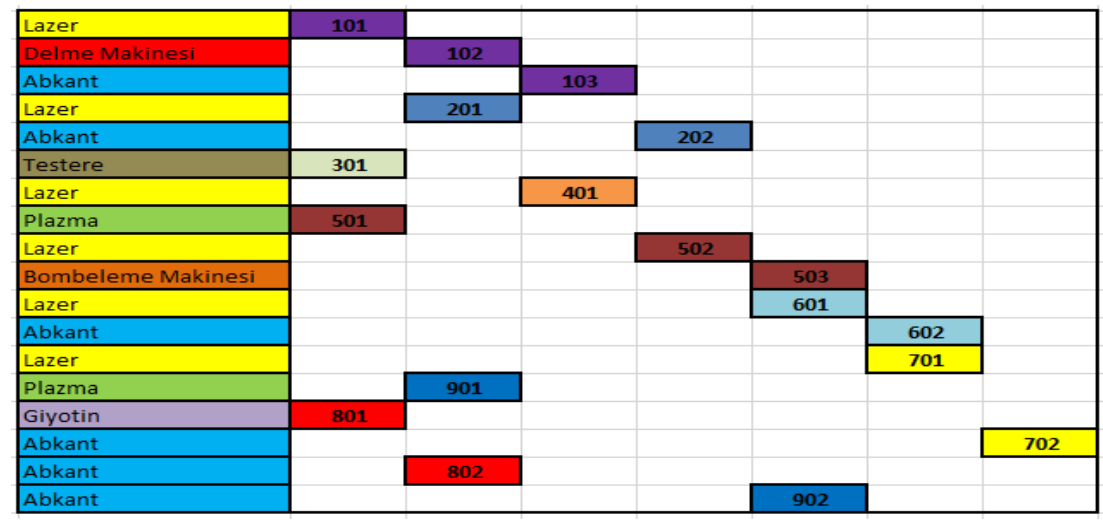

Şekil 1. İşlem bazlı Gantt diyagramı

\begin{tabular}{|c|c|c|c|c|c|c|c|}
\hline Lazer & 101 & 201 & 401 & 502 & 601 & 701 & \\
\hline Delme Makinesi & & 102 & & & & & \\
\hline Abkant & & 802 & 103 & 202 & 902 & 602 & 702 \\
\hline Testere & 301 & & & & & & \\
\hline Plazma & 501 & 901 & & & & & \\
\hline Bombeleme Makinesi & & & & & 503 & & \\
\hline Giyotin & 801 & & & & & & \\
\hline
\end{tabular}

Şekil 2. Makine bazlı Gantt diyagramı

Çizelgeleme problemleri için çeşitli sınıflandırma tipleri mevcuttur. Bunlar;

1. Kaynak kısıtlı proje çizelgeleme ve makine çizelgeleme,

2. Deterministik makine çizelgeleme ve stokastik makine çizelgeleme olarak incelemektedir.

Kaynak kısıtlı makine çizelgeleme problemleri, üretim çizelgeleme problemlerinin en genel halidir. Makine, enerji, para ve personel kısıtları kaynak olarak göz önünde bulundurulurken makine bekleme süreleri en küçüklemeye çalışılarak toplam sürenin minimizasyonu sağlanmaya çalışılmaktadır. Dolayısıyla maliyetler en küçüklenecektir. İşlemler arası bekleme süreleri çizelgelemede kullanılan öncelik yöntemleri ile ilişkilidir. Çizelgeleme yapılırken ana amaç her kaynağın kapasitesini aşmadan ve öncelik yöntemlerine uyularak makinelere atanmasidir.

Eğer incelenen veriler, serbest kalma zamanları ve işlem süreleri gibi, tam doğrulukla biliniyor ise deterministik makine çizelgeleme, bilinmiyor fakat olasılıklı olarak tahmin edilebiliyor ise stokastik makine çizelgeleme problemi olarak adlandırılırlar. Çizelgeleme problemlerinin genel sınıflandırılması Şekil 3'de gösterilmiştir. 


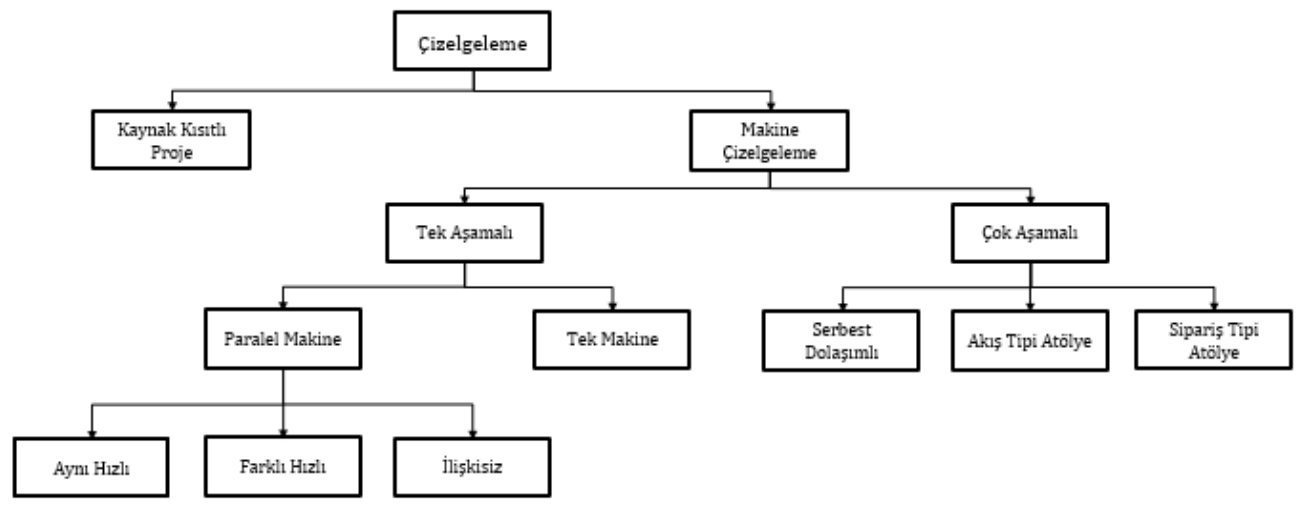

Şekil 3. Çizelgeleme problemlerinin genel sınıflandırılması [15]

Kaynak kısıtlı proje çizelgeleme problemlerinde, bir projenin oluşturulması için kısıtlı kaynaklar kullanılır. Öncelik kuralları da göz önüne alınarak en iyi çizelgeleme modeli oluşturulur. Kaynak kısıtlı proje çizelgeleme problemleri tanımlanırken bazı varsayımlarda bulunulur. $\mathrm{Bu}$ varsayımlar aşağıdaki şekilde sıralanmıştır;

- Faaliyet süreleri deterministiktir.

- Faaliyetlerin gerçekleştirilmesi için gerekli birim zaman kaynak kullanımı sabittir.

- Herhangi bir faaliyet için atanan kaynak o faaliyette kullanıldığı süreç içerisinde iken başka faaliyetler tarafından kullanılamaz.

- Kaynak kullanımına başlayan faaliyet yarıda kesilemez veya ara verilemez.

- Başlatılan faaliyetler iptal edilemez.

Makine çizelgeleme problemleri tek ve çok aşamalı problemler olarak ikiye ayrılmaktadır. Tek aşamalı problemlerde her işin tek bir işlemden oluştuğu kabul edilirken çok aşamalı makine çizelgeleme problemlerinde bir işin yapılması için çok sayıda işlemin yapılması gerektiği kabul edilir.

Tek aşamalı makine çizelgeleme problemleri kendi aralarında paralel makineli ve tek makineli olarak ikiye ayrılır. Tek aşamalı tek makineli problemler, çizelgeleme problemlerinin en basit halidir. Tek aşamalı paralel makineli problemlerde tek işlemden oluşan işlerin gerçekleştirilmesi için birden fazla makine bulunmaktadır. Paralel makineli problemler de tiplerine bağlı olarak üç farklı dala ayrılmıştır. Bunlar; aynı hızlı paralel makineler, farklı hızlı paralel makineler ve ilişkisiz paralel makinelerdir. Aynı hızlı paralel makinelerde herhangi bir işin işlem süresi tüm makinelerde aynıdır. Farklı hızlı paralel makinelerde makine hızları işlerin özelliklerine bakılmaksızın farklılık göstermektedir. Örneğin herhangi bir sac kesme işlemi giyotin makinesinde üç birim süreye ihtiyaç duyarken, lazer makinesinde beş birim süreye ihtiyaç duyabilir. İlişkisiz paralel makinelerde ise farklı hızlara sahip paralel makineler ile özdeş paralel makilerin genel durumudur.

Çok aşamalı makine çizelgeleme problemleri günümüzde birçok firma tarafından kullanılan çizelgeleme problemlerindendir. Bu problemler izledikleri rotalara göre üçe ayrılmaktadır. Bunlar; serbest dolaşımlı, akış tipi atölye ve sipariş tipi atölyedir. Çok aşamalı serbest dolaşımlı makine çizelgeleme problemlerinde ürünün üretilmesi için gerekli işlemler arasında öncelik ilişkisi bulunmamaktadır. Akış tipi atölye problemlerinde $n$ adet iş $\mathrm{m}$ adet üretim merkezinde işlem görürken tüm işler belirli bir rotayı takip ekmektedir. Sipariş tipi atölye çizelgeleme de ise akış tipi atölye çizelgelemeden farklı olarak rotalama kısıtı bulunmamaktadır. 
$\mathrm{Bu}$ yöntemlerin yanı sıra işlerin geliş şekline göre statik ve dinamik makine çizelgeleme problemleri olarak da bir ayrım yapılabilmektedir. Eğer çizelgelenecek iş kümesi zamana bağlı olarak değişmiyor ise problem statik, değişiyorsa dinamik olarak belirtilmektedir.

Bu çalışmada uygulama esnasında çalışılan fabrikada ürünlerin üretimleri için belirli rotalar mevcuttur. Bu nedenle çok aşamalı akış tipli makine çizelgeleme problemlerine uyum sağlamaktadır.

\section{B. Çizelgelemede Kullanulan Öncelik Kuralları ve Kabuller}

Firmalarda en çok kullanılan öncelik kuralları aşağıda listelenmiştir:

-İlk giren ilk çıar,

-Erken teslim tarihli,

-Kalan işlem zamanl1,

-Kısa işlem zamanlı,

-Uzun işlem zamanlı,

-Toplam işlem zamanl1,

-Çok operasyonu kalan öncelik kuralı,

-Az operasyonu kalan öncelik kuralı,

-Dinamik değişkenli,

-Rassal öncelik kuralıdır.

Çalışma kapsamında bu kurallardan ilk giren ilk çıkar, erken teslim tarihli, kısa işlem zamanlı, uzun işlem zamanlı olmak üzere dört tanesi üzerinde durulmuştur.

Akış tipli çizelgeleme problemlerinin çözümünde bazı kabullemeler yapılır. Bu kabuller;

-Aynı işin iki farklı operasyonu aynı anda yapılamaz.

-Başlanan iş eksik bırakılamaz.

-Herhangi bir iş için önceden rezervasyon yapılamaz.

-Bir makinede yeni bir işin başlayabilmesi için önceki işin bitmiş olması gerekir.

-Hiçbir makine aynı anda iki işi yapamaz.

-Hazırlık süreleri çizelgelemeden bağımsızdır ve makineler arası taşıma süreleri ihmal edilir.

-Makinelerin boşta kalma süreleri olabilir.

-İşs sayısı bilinmektedir.

-Makine arızalanmaları göz ardı edilir.

-İşlem zamanları bilinmektedir.

-Makine sayısı bilinmektedir. 


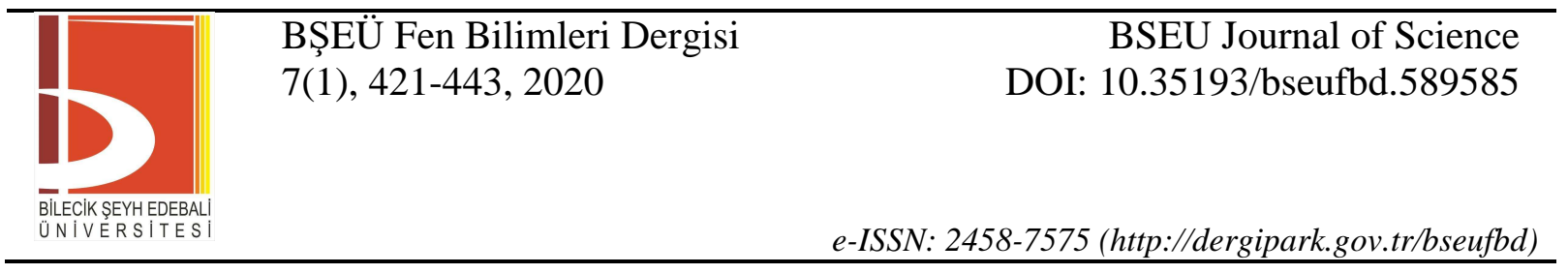

\section{ARAȘTIRMA BULGULARI}

$\mathrm{Bu}$ bölümde çalışmanın yapıldığı firma hakkında bilgiler verilmiş, firmanın yerleşim planı çizilmiştir. Mevcut ürünleri ürün kodları ile birlikte istenmiş ve her ürün için akış şemaları ve zaman etüdü çalışmaları çizilmiştir. Bu veriler veri tabanına kaydedilerek mevcut siparişleri kayıt altına alınmıştır. Bu siparişler üzerinden çizelgeleme işlemleri yapılacaktır. Bu bölümde aynı zamanda yazılan program ve uygulama ile ilgili bilgiler verilmiştir.

\section{A. Firma Bilgileri}

Bu bölümde firma ile ilgili genel bilgiler verilmiştir. Firmanın ürettiği ürünler ve akış şemaları, birim süreleri ile birlikte paylaşılmıştır.

Firma makine, mobilya ve mutfak, otomatik kepenk, otomatik pergole, pano medikal ve tıbbi cihaz imalatçıları, sanayi tipi buzdolabı üreticileri, inşaat firmaları, aydınlatmacılar, reklam ve tabelacılar gibi birçok müşteriye parça ve ürün hizmeti vermektedir.

Firmanın yerleşim planı Şekil 4'de gösterilmiştir. Her tezgâhta kaç kişi çalıştığı ve ürün rotaları şekil üzerinde belirtilmiştir.

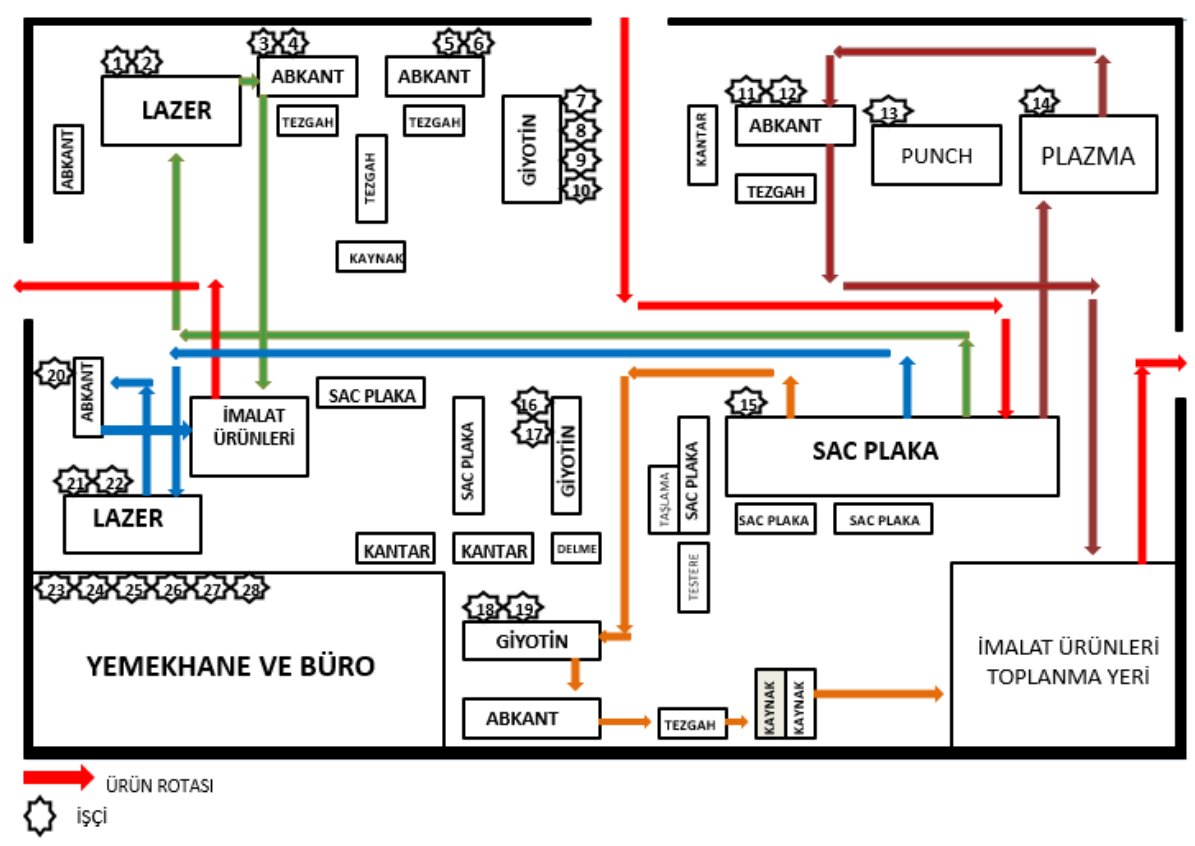

Şekil 4. Firma yerleşim planı

Sac metal parçaların kesilmesi ve delinmesi, bükme kalıplamayla şekillendirilmesi, kaynak yaparak birleştirilmesi ve ortaya çıkan ürünlerin boyanarak son haline getirilmesiyle kaliteli bir hizmet sunulması hedeflenmiştir. Firmada otuza yakın personel çalışmaktadır. Firmanın ürettiği ürünlerden bazıları Tablo 1'de verilmiştir. 


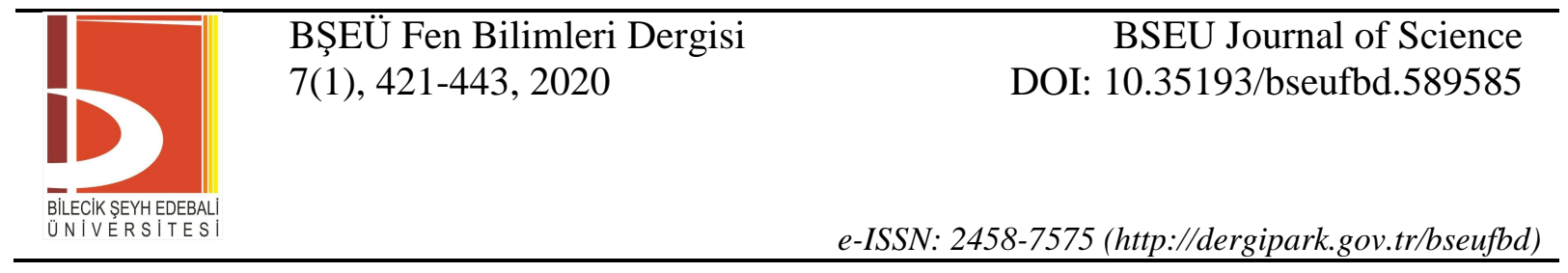

Tablo 1. Ürün listesi

\begin{tabular}{ccccc}
\hline No & Ürün Kodu & Ürün Adı & Yapıldığı Malzeme & Satış Miktarı \\
\hline 1 & YYKTS01 & Yay Kutusu & Sac & $\% 65-\% 70$ \\
2 & BYRK01 & Bayrak & Sac & $\% 17-\% 25$ \\
3 & BRBS01 & Boru Başı & Sac & $\% 31-\% 35$ \\
4 & DVLMBZ01 & Davlumbaz & Sac & $\% 20-\% 30$ \\
5 & PRFTP01 & Profil Tapa & Sac & $\% 55-\% 70$ \\
6 & OLK01 & Oluk & Sac & $\% 68-\% 75$ \\
7 & YY01 & Yay & Çelik & $\% 85-\% 96$ \\
8 & LML01 & Lamel & Sac & $\% 75-\% 84$ \\
\hline
\end{tabular}

Üretilen ürünlerden yay, şaft, profil tapa, bayrak, oluk, lamel, yay kutusu ve boru başı kepenk üretiminde kullanılmaktadır. Firma ürünlerini hem yarı mamul olarak satmakta hem de montajını yapıp kepenk olarak satmaktadır. Firmada üretilen bu ürünlerin resimleri Şekil 5'de gösterilmiştir.

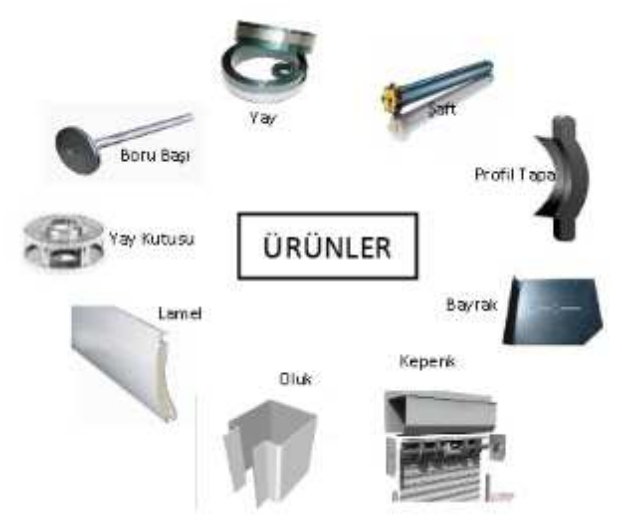

Şekil 5. Ürün resimleri

Kepenk üretimi için akış şeması Şekil 6'da gösterilmiştir. Kepenk üretiminde kullanılan yarı mamullerin üretim aşamaları daha sonra gösterilecektir.

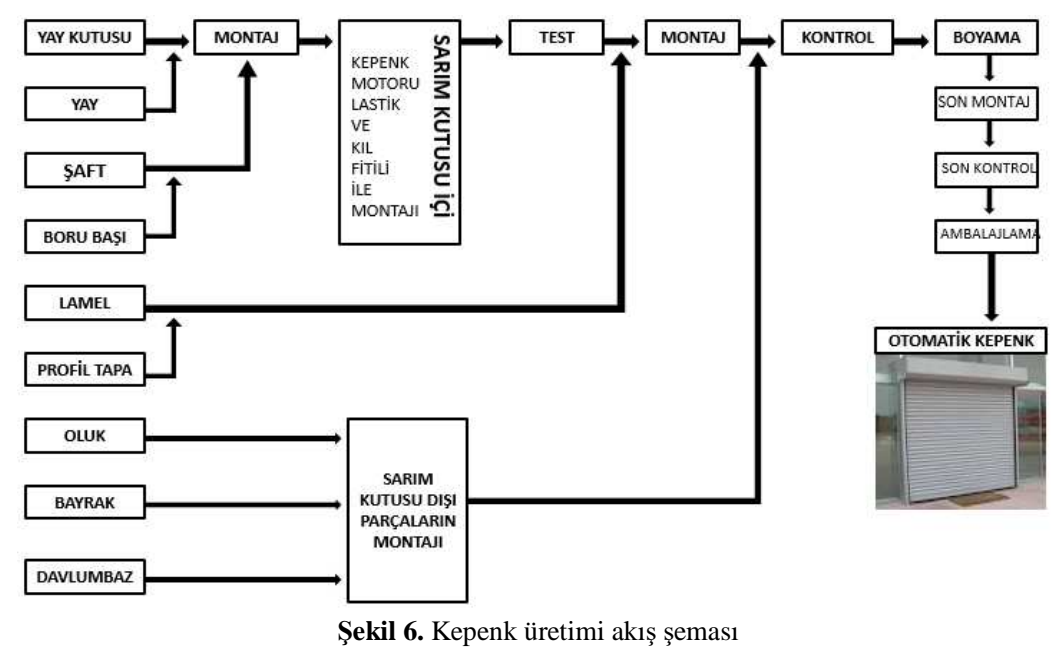




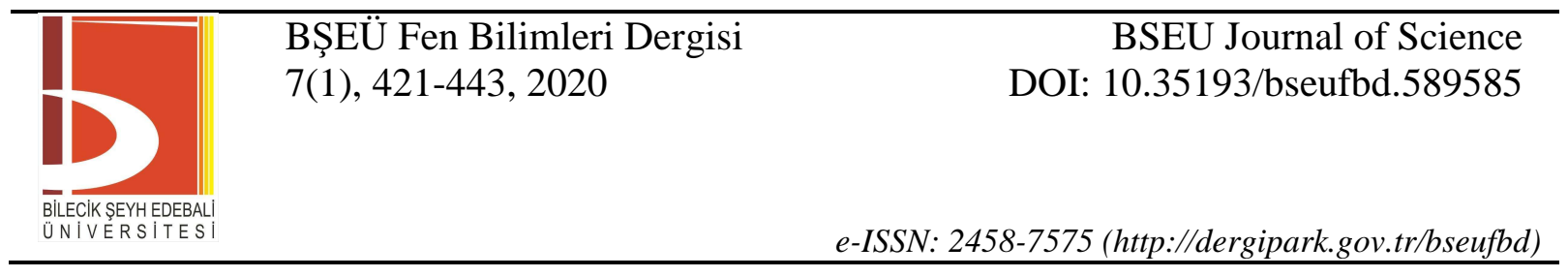

Firma da zaman etüdü çalışması yapılarak birim zamanlar hesaplanmıştır. Tablo 2'de tutulan süreler gösterilmiştir.

Tablo 2. İmalat adımları işlem süreleri

\begin{tabular}{|c|c|c|c|c|c|c|c|c|c|}
\hline \multirow{2}{*}{ işLEM NO } & \multirow{2}{*}{\multicolumn{2}{|c|}{ IMALAT ADIMLARI }} & \multirow{2}{*}{ iş iSTASYONU } & \multicolumn{2}{|c|}{ SÜRE 1 (5n) } & \multicolumn{2}{|c|}{ SÜRE Z (sn) } & \multicolumn{2}{|c|}{ SÜRE 3 (sn) } \\
\hline & & & & H.S. & i.s. & H.S. & i.s. & H.S. & i.5. \\
\hline \multirow[t]{4}{*}{100} & \multicolumn{3}{|c|}{ YAY KUTUSU } & & & & & & \\
\hline & 101 & Sac Kesme & Lazer & 324,70 & 43,90 & 358,30 & 40,40 & 316,90 & 42,10 \\
\hline & 102 & Sac Delme & Delme Makinesi & 248,90 & 11,30 & 247,90 & 13,60 & 246,70 & 12,50 \\
\hline & 103 & Sac Kivrma & Abkant & 257,50 & 128,40 & 261,50 & 122,30 & 249,10 & $131, .6$ \\
\hline \multirow[t]{3}{*}{200} & \multicolumn{3}{|c|}{ YAY } & & & & & & \\
\hline & 201 & Çelik Kesme & Lazer & 403,40 & 52,60 & 412,50 & 49,60 & 421,30 & 51,60 \\
\hline & 202 & Çelik Kivirma & Abkant & 167,10 & 134,90 & 163,20 & 126,20 & 175,50 & 125,10 \\
\hline \multirow[t]{2}{*}{300} & \multicolumn{3}{|c|}{ ŞAFT } & & & & & & \\
\hline & 301 & Boru Kesme & Testere & 457,20 & 521,40 & 462,60 & 547,40 & 432,80 & 537,40 \\
\hline \multirow[t]{2}{*}{400} & \multicolumn{3}{|c|}{ BORU BAŞI } & & & & & & \\
\hline & 401 & Sac Kesme & Lazer & 154,20 & 84,80 & 148,10 & 81,60 & 160,40 & 78,60 \\
\hline \multirow[t]{4}{*}{500} & \multicolumn{3}{|c|}{ LAMEL } & & & & & & \\
\hline & 501 & Sac Kesme & Plazma & 320,8 & 103,6 & 312,5 & 105,3 & 347,1 & 101,9 \\
\hline & 502 & Sacșekillendirme & Lazer & 258,6 & 245,5 & 251,3 & 241,1 & 264,8 & 247,7 \\
\hline & 503 & Sac Bombeleme & Bombeleme Mak. & 186,5 & 201,3 & 179,3 & 203,5 & 192,7 & 197,6 \\
\hline \multirow[t]{3}{*}{600} & \multicolumn{3}{|c|}{ PROFILTAPA } & & & & & & \\
\hline & 601 & Sac Kesme & Lazer & 329,7 & 213,9 & 361,8 & 225,4 & 314,3 & 216,8 \\
\hline & 602 & Sac Krvrma & Abkant & 276,2 & 143,1 & 268,7 & 137,6 & 295,7 & 157,8 \\
\hline \multirow[t]{3}{*}{700} & \multicolumn{3}{|c|}{ OLUK } & & & & & & \\
\hline & 701 & Sac Kesme & Lazer & 243,3 & 201,5 & 247,6 & 193,3 & 251,9 & 215,3 \\
\hline & 702 & Sac Kivrma & Abkant & 186,7 & 105,1 & 179,8 & 107,5 & 175,1 & 103,9 \\
\hline \multirow[t]{3}{*}{800} & \multicolumn{3}{|c|}{ BAYRAK } & & & & & & \\
\hline & 801 & Sac Kesme & Giyotin & 164,9 & 1201,8 & 174,9 & 1212,2 & 171,5 & 1215,7 \\
\hline & 802 & Sac Krvrma & Abkant & 233,3 & 86,2 & 251,4 & 94,4 & 227,3 & 81,2 \\
\hline 900 & & DAVLUMBA & & & & & & & \\
\hline & 901 & Sac Kesme & Plazma & 329,6 & 75,9 & 348,5 & 71,8 & 367,3 & 63,9 \\
\hline & 902 & Sac Krvrma & Abkant & 269,8 & 92,6 & 261,5 & 86,5 & 254,8 & 97,7 \\
\hline 1000 & & SARIM KUTU & & & & & & & \\
\hline & 1001 & Montaj & Kaynak Makinesi & 679,2 & 2795,4 & 667,9 & 2862,3 & 691,4 & 2791,7 \\
\hline 1100 & & TEST & & & & & & & \\
\hline & 1101 & Sanm Kontrolü & Test & 607,5 & 736,3 & 615,7 & 743,5 & 603,2 & 756,9 \\
\hline 1200 & & ARA MONT & & & & & & & \\
\hline & 1201 & Ara Montaj & Kaynak Makinesi & 824,4 & 3796,7 & 851,8 & 3906,1 & 864,6 & 3754,2 \\
\hline 1300 & & BOYAMA & & & & & & & \\
\hline & 1301 & Toz Boyama & Boya Kabini & 472,1 & 3600 & 465,6 & 3600 & 438,8 & 3600 \\
\hline & 1302 & Finnlama & Finn & 276,7 & 2700 & 261,4 & 2700 & 254,7 & 2700 \\
\hline 1400 & & SON MONT & & & & & & & \\
\hline & 1401 & Kapaklann Montaji & Kaynak Makinesi & 1247,6 & 647,1 & 1235,8 & 654,5 & 1231,5 & 637,7 \\
\hline 1500 & & SON KONTR & & & & & & & \\
\hline & 1501 & Son Kontrol & Kontrol & 305,5 & 601,8 & 298,6 & 596,9 & 314,3 & 607,7 \\
\hline 1600 & & AMBALALAR & & & & & & & \\
\hline & 1601 & Ambalajlama & Ambalajama & 201,3 & 509,7 & 218,4 & 512,1 & 209,9 & 496,5 \\
\hline
\end{tabular}

Ayrıntılı iş akış şemaș işlem numaraları ile birlikte çizilmiş ve Şekil 7'de gösterilmiş̧ir. 

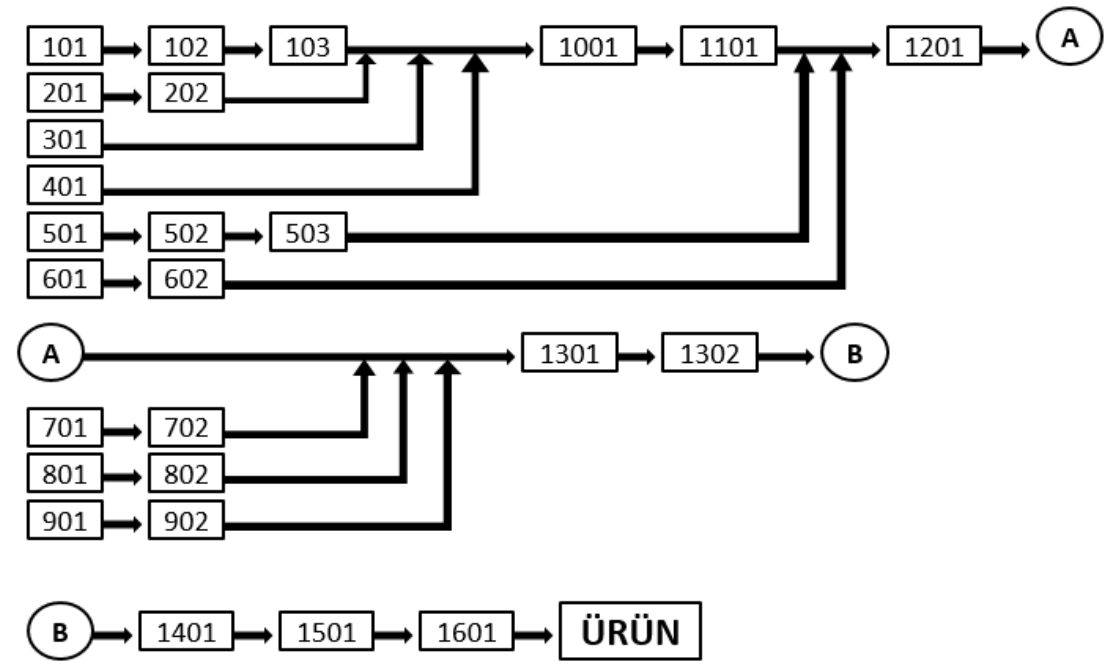

Şekil 7. Ayrıntılı iş akış şeması kullanılmıştır.

Ürünlerin üretimi için gerekli birim süreler Access dosyasına aktarılarak program için veri olarak

\section{B. Yazılımı ve Uygulama}

Çizelgeleme yapmak zor ve karmaşık bir iştir. Bunu basitleştirmek amacı ile bir çizelgeleme paket programı yazılımı yapılmıştır. Program iki bölümden oluşmaktadır. İlk bölüm (Veri Kayıt) 6 sekmeden oluşmaktadır ve veri tabanı işlemlerini içermektedir. Firmalar çizelgeleme yapmayacak olsa dahi bu bölümü kullanarak veri saklama işlemi gerçekleştirebilir. İkinci bölüm (Çizelgeleme) ilgili verileri kullanarak Gantt şeması ile çizelgeleme işlemi gerçekleştirmektedir.

1) Veri Kayıt Bölümü: Müşteri, makine, ürün, üretim, sipariş ve çizelge sekmelerinden oluşmaktadır. Müşteri, makine ve ürün sekmelerinin çalışma prensipleri aynıdır. Müşteri sekmesi için tasarım ekranı Şekil 8'de gösterilmiş̧ir. Bu bölümde müş̧eri ile ilgili veriler kayıt altına alınmaktadır.

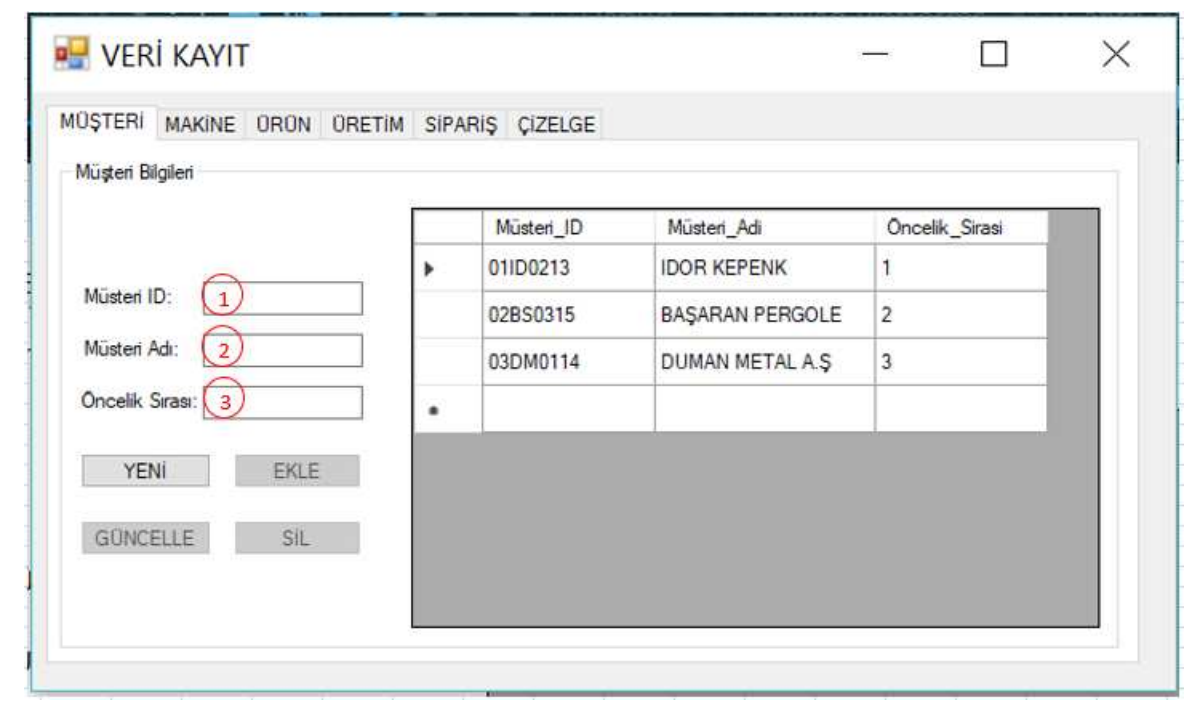

Şekil 8. Müşteri sekmesi tasarım ekranı 
Firma yeni bir müşteri ile anlaşma yaptığında Müşteri ID, Müşteri Adı ve firma için bir öncelik belirtiyor ise Öncelik Sırası verilerini sırası ile 1, 2 ve 3 numaralı kutulara yazarak EKLE butonuna tıklamalıdır. Mevcut bir müşteri üzerinde bir değişiklik yapması gerekiyor ise ilgili müşteriyi tablodan seçerek istediği bölümü değiştirmeli daha sonra GÜNCELLE butonuna tıklamalıdır. Son olarak anlaşması fes edilen müşterileri veri tabanında silmek için tablodan müşteriyi seçtikten sonra SILL butonuna tıklayarak işlemi gerçekleştirebilir.

Makine ve ürün sekmelerinde de aynı şekilde makine ve ürün bilgileri kayıt altına alınmaktadır. Üretim ve sipariş sekmelerinin çalışma prensipleri de benzerdir. Ancak eklenmesi gereken veriler farklılık gösterir. Şekil 9'da üretim sekmesi kullanıcı ekranı verilmiştir.

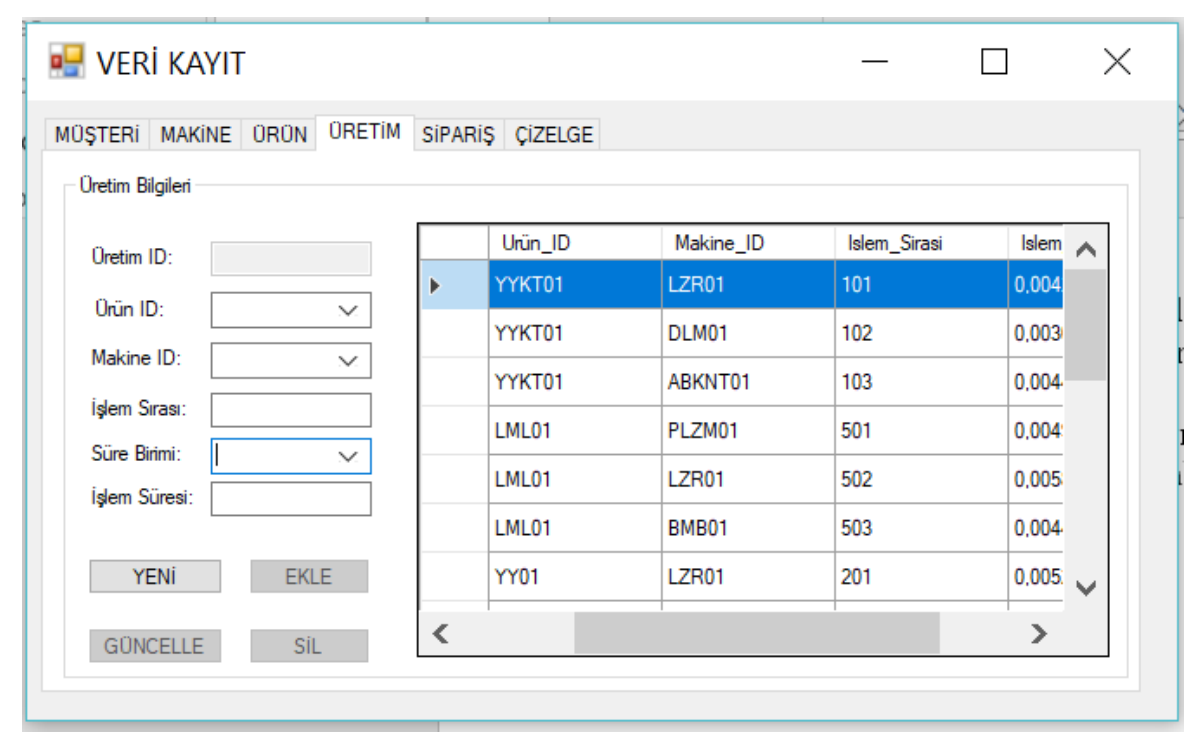

Şekil 9. Üretim sekmesi tasarım ekranı

Üretim sekmesinde bir ürünün üretilmesi için hangi aşamalardan geçtiği kayıt altına alınmaktadır. Kullanıcı öncelikle Ürün ID kutusundan hangi ürünün üretimini kayıt altına alacağını seçer. Daha sonra bu ürünün üretilmesi için gerekli olan makinenin ID numarasını seçer ve bu makinedeki işleminin hangi sırada gerçekleşeceğini İşlem Sırası kutusuna yazar. Bu işlemin ne kadar sürdüğü ve zaman birimi olarak ne kullanıldığı verileri girilerek EKLE butonuna tıklanır. Gantt şeması oluşturulurken işlem sırası, süre birimi ve işlem sürelerinin doğruluğu önem arz etmektedir. Yanlış kaydedilen verilerin tablodan seçilerek güncelleme yapılması veya silinerek yeniden kaydedilmesi gerekmektedir.

Gelen siparişlerin kayıt altına alınması için Sipariş sekmesi kullanılır. Sekmenin kullanıcı ara yüzü Şekil 10 'da gösterilmiştir. 


\begin{tabular}{|c|c|c|}
\hline & $\begin{array}{l}\text { BŞEÜ Fen Bilimleri Dergisi } \\
7(1), 421-443,2020\end{array}$ & $\begin{array}{r}\text { BSEU Journal of Science } \\
\text { DOI: } 10.35193 / \text { bseufbd.589585 }\end{array}$ \\
\hline & & 58-7575 (http://dergipark.gov.tr/bseufbd) \\
\hline
\end{tabular}

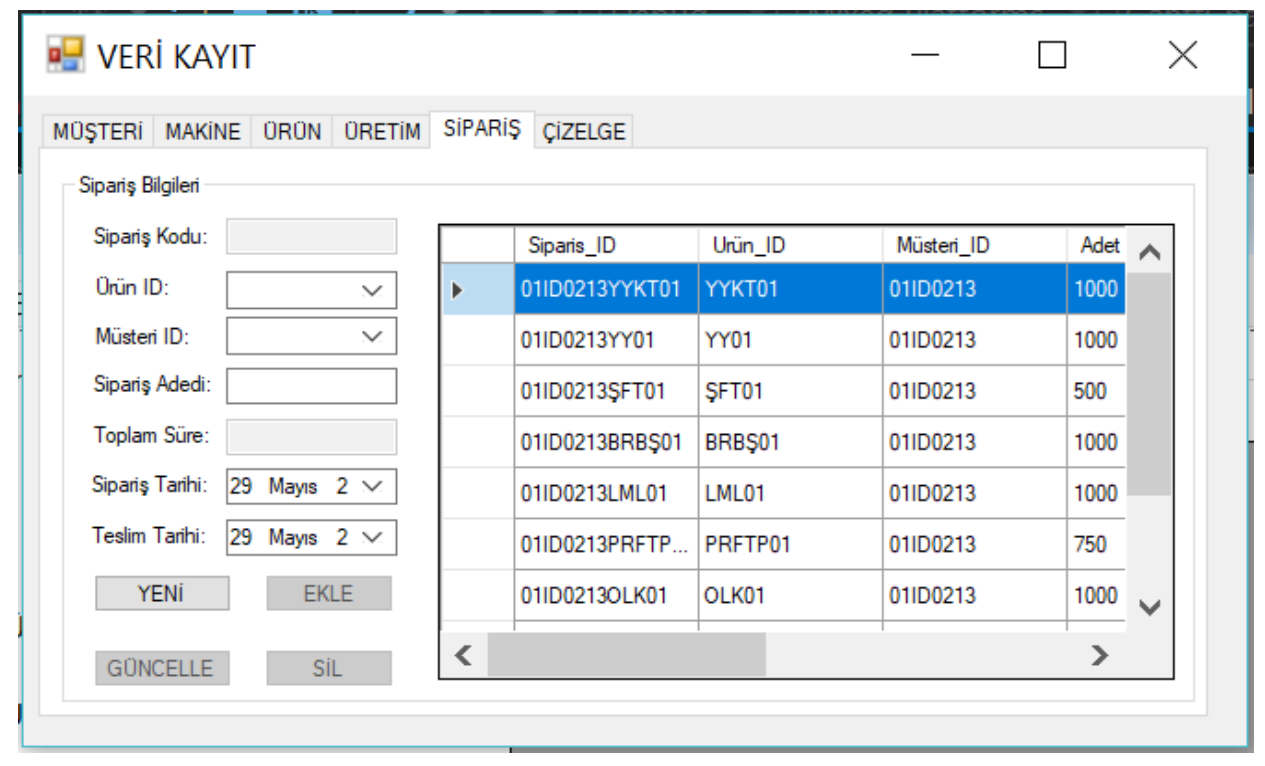

Şekil 10. Sipariş sekmesi tasarım ekranı

Kullanıcı sipariş verilen ürünün ID numarasını ve hangi müş̧erinin siparişi olduğuna dair müşteri ID numarasını seçer. Daha sonra sipariş adedi, sipariş tarihi ve teslim tarihi bilgilerini doldurur. Toplam sipariş süresi sistem tarafından otomatik olarak hesaplanmaktadır. Bu hesap için öncelikle seçilen ürünün üretim bilgilerinden toplam birim süre hesaplanır. Daha sonra girilen sipariş adedi ile birim süre çarpılarak toplam süre bulunur. Sipariş kodu bize ürün ve müşteri hakkında bilgi vermektedir. Veriler eksiksiz bir biçimde girildikten sonra EKLE butonuna tıklatılarak verilerin sisteme aktarılması sağlanır. Yanlış eklenen veya değiştirilmesi gereken veriler tablodan seçilerek ilgili yer değiştirilmeli daha sonra GÜNCELLE butonuna tıklanmalıdır. Silinmesi gereken veriler ise tablodan seçilerek SíL butonuna tıklanır.

Veri kayıt bölümün son sekmesi aynı zamanda çizelgeleme bölümü ile bağlantı sağlar. Şekil 11'de bu sekmenin kullanıcı ara yüzü gösterilmiştir.

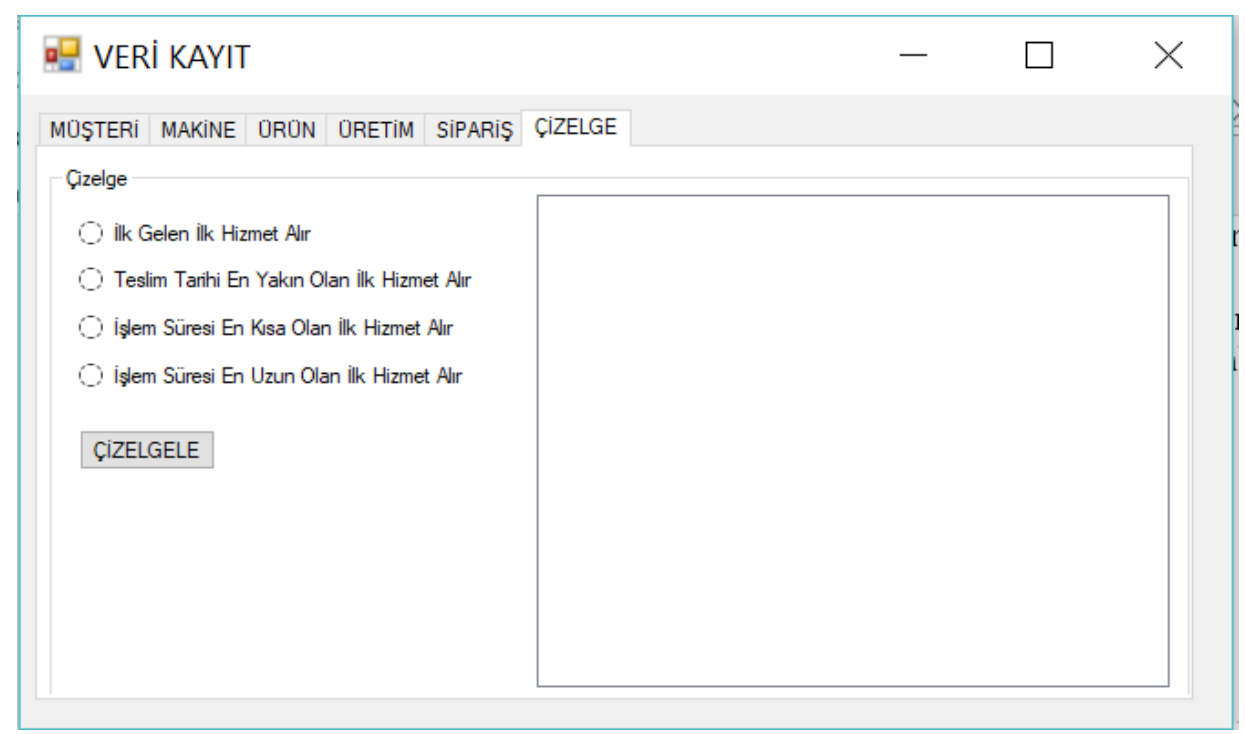

Şekil 11. Çizelge sekmesi tasarım ekranı 
Çizelgeleme işlemi yapacak olan kişi kullanmak istediği yöntemi seçerek Çi̇ZELGELE butonuna tıklamalıdır. İstenen özel bir çizelgeleme yöntemi yoksa tüm yöntemler kullanılarak en kısa üretim süresine sahip olan çizelgeleme yöntemi tespit edilir. Daha sonra tespit edilen çizelgeleme yöntemine göre ürünlerin üretimine başlanır.

2) Çizelgeleme Bölümü: Çizelgeleme dinamik bir iştir. $\mathrm{Bu}$ nedenle yerleştirme işlemi kurallara dayandırılarak yapılır. Çizim yapılırken ileri doğru çizelgeleme sabit kabul edilmiş, öncelik kuralı seçimi kullanıcıya bırakılmıştır. Çizelgeleme bölümü ana çalışma prensibi Şekil 12'de gösterilmiştir. Çizelgeleme yapılırken kullanılan veriler programın alt yapısında kullanılan veri tabanından çekilir. Bu veri tabanında müşterilerin, firmada bulunan makinelerin, firmanın ürettiği ürünlerin ve her ürünün nasıl üretildiği ile ilgili üretim aşamalarının bilgileri bulunur. Yeni bir sipariş verildiğinde sistem öncelikle bu siparişin hangi müşteriye ait olduğunu ve hangi ürünü sipariş ettiğini sistemden çekerek ürünün üretim aşamalarının bağlantısına ulaşır. Yeni sipariş kullanılan çizelgeleme yöntemine göre uygun yerlere yerleştirilerek üretime alınır. Yöntemler ile ilgili ayrıntılı çalışma prensipleri Şekil 12’nin devamı niteliğinde paylaşılacaktır.

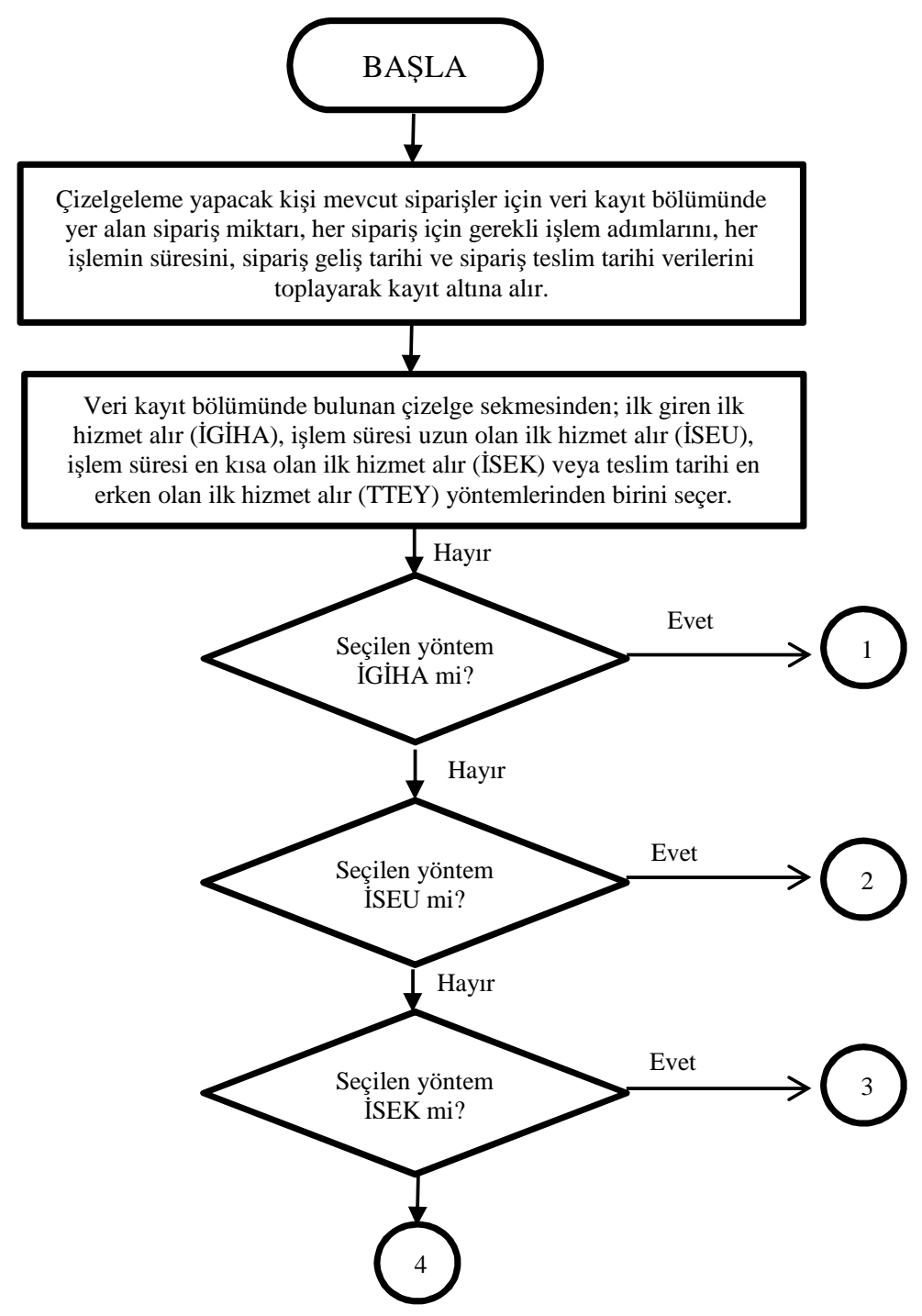

Şekil 12. Çizelgeleme bölümü ana çalışma prensibi 
İlk giren ilk hizmet alır yönteminde gelen siparişlerin üretim merkezine geliş sıralarına (sipariş geliş tarihi) göre makine yükleme işlemi gerçekleştirilir. Özellikle dinamik atölye ortamlarındaki işlere, daha adaletli olabilmek amacı ile kullanılır. İmalat ortamlarında daha çok, hizmet sektörlerinde müşteriye eşit davranabilmek için kullanılan bir yöntemdir.

Sistemin çalışma prensibini anlayabilmek amacı ile ilk giren ilk çıkar (İGİHA) kuralının program içerisindeki döngüsü Şekil 13'de gösterilmiştir.

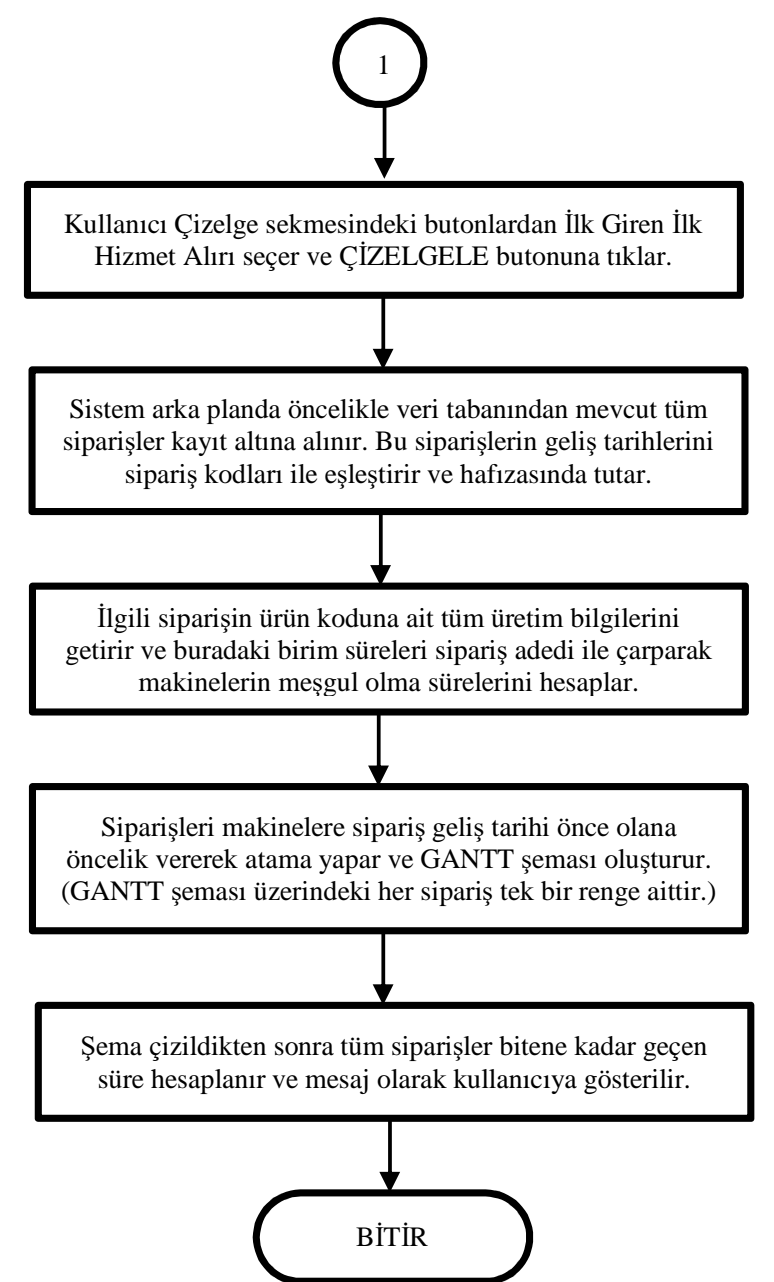

Şekil 13. İlk giren ilk hizmet alır kuralının program içerisindeki döngüsü

En uzun işlem süresine göre çizelgeleme yönteminde gelen siparişlerin üretim merkezine geliş sıralarının yanı sıra siparişlerin toplam üretim süresinin uzunluğuna göre makine yükleme işlemi gerçekleştirilir. Bu yöntemde işlem süresi uzun olan siparişin önceliği vardır.

Sistemin çalışma prensibini anlayabilmek amacı ile işlem süresi en uzun olan ilk hizmet alır (İSEU) kuralının program içerisindeki döngüsü Şekil 14'de gösterilmiştir. 


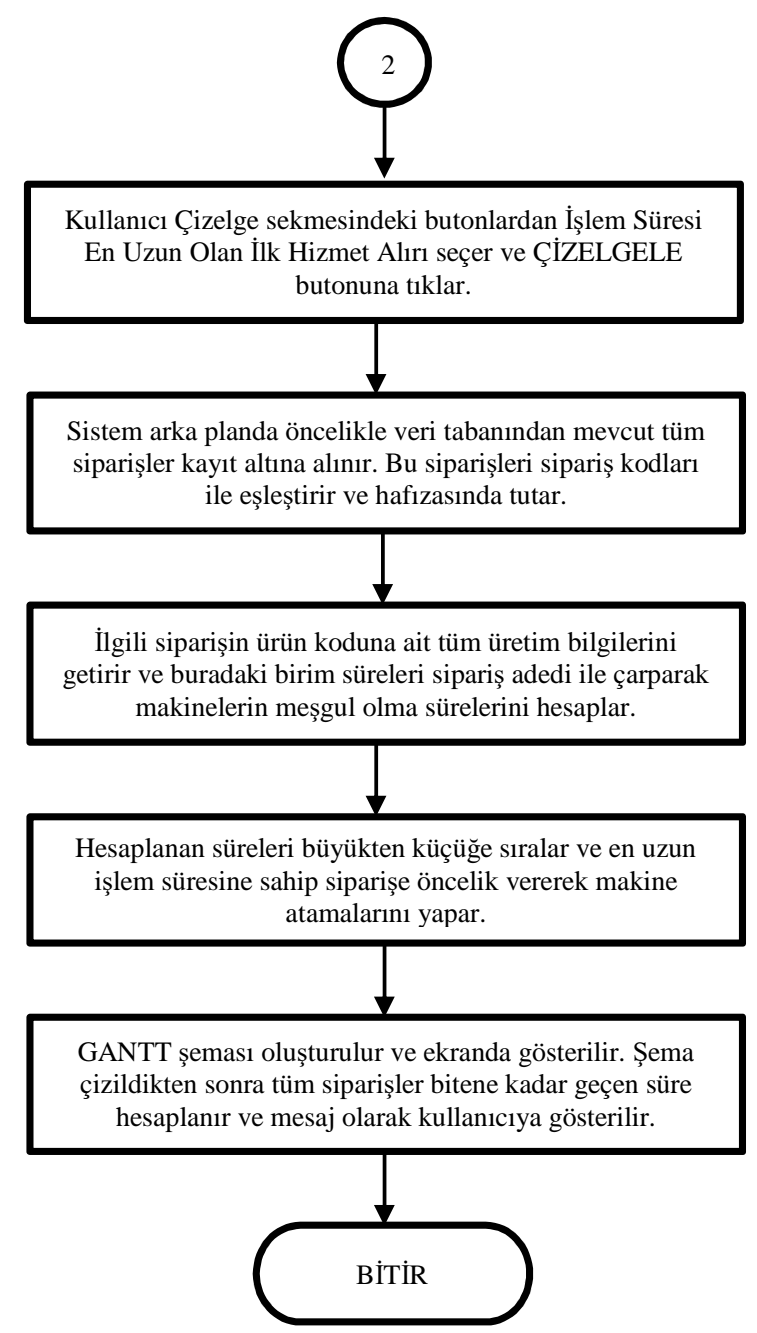

Şekil 14. İşlem süresi en uzun olan ilk hizmet alır kuralının program içerisindeki döngüsü

En kısa işlem süresine göre çizelgeleme yönteminde gelen siparişlerin üretim merkezine geliş zamanları ve teslimat zamanları göz ardı edilerek toplam üretim süresinin uzunluğuna göre makine yükleme işlemi gerçekleştirilir. Bu yöntemde işlem süresi en kısa olan siparişin önceliği vardır.

Sistemin çalışma prensibini anlayabilmek amacı ile işlem süresi en kısa olan ilk hizmet alır (İSEK) kuralının program içerisindeki döngüsü Şekil 15'de gösterilmiştir. 


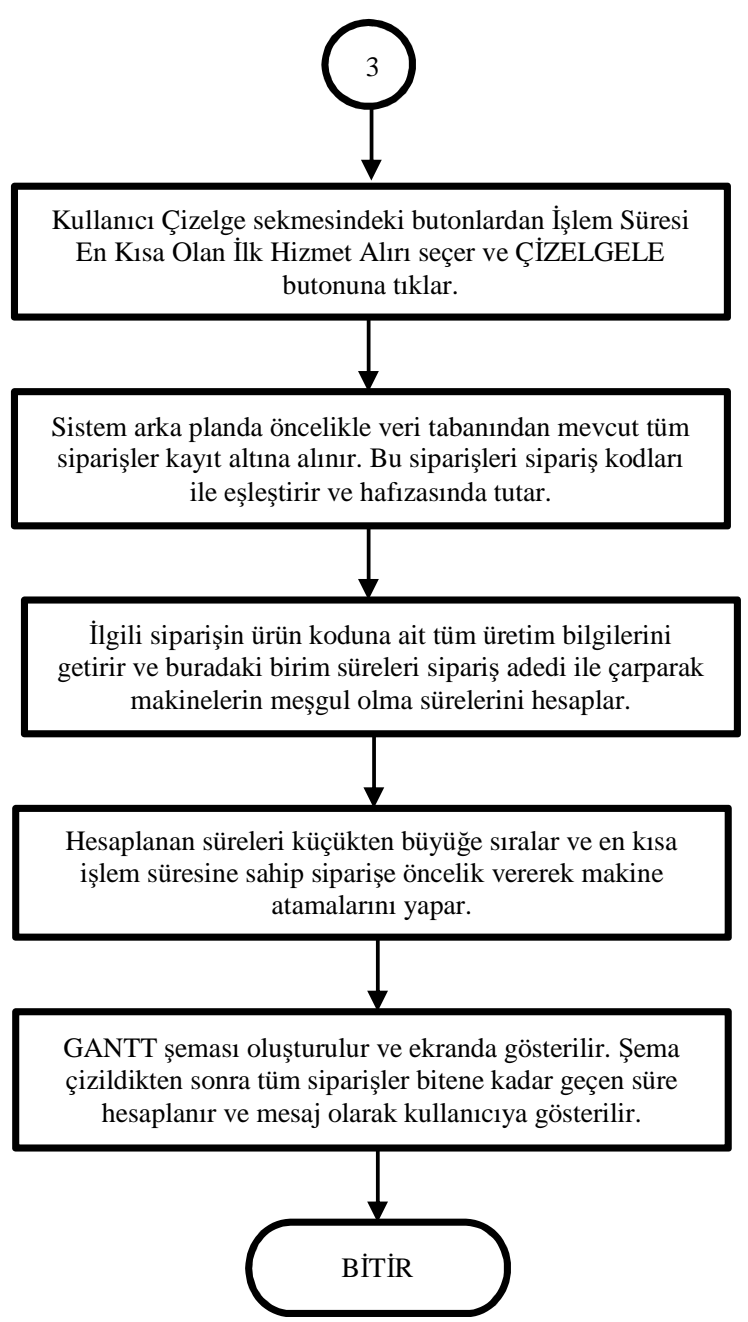

Şekil 15. İşlem süresi en kısa olan ilk hizmet alır kuralının program içerisindeki döngüsü

Teslim tarihi en yakın olan ilk hizmet alır yönteminde gelen siparişlerin sipariş teslim tarihleri göz önüne alınarak makine yükleme işlemi gerçekleştirilir. Sipariş teslim tarihleri aynı olan siparişler içerisinden rastgele bir seçim yapılarak yerleştirilir.

Sistemin çalışma prensibini anlayabilmek amacı ile teslim tarihi en yakın olan ilk hizmet alır (TTEY) kuralının program içerisindeki döngüsü Şekil 16'da gösterilmiştir. 


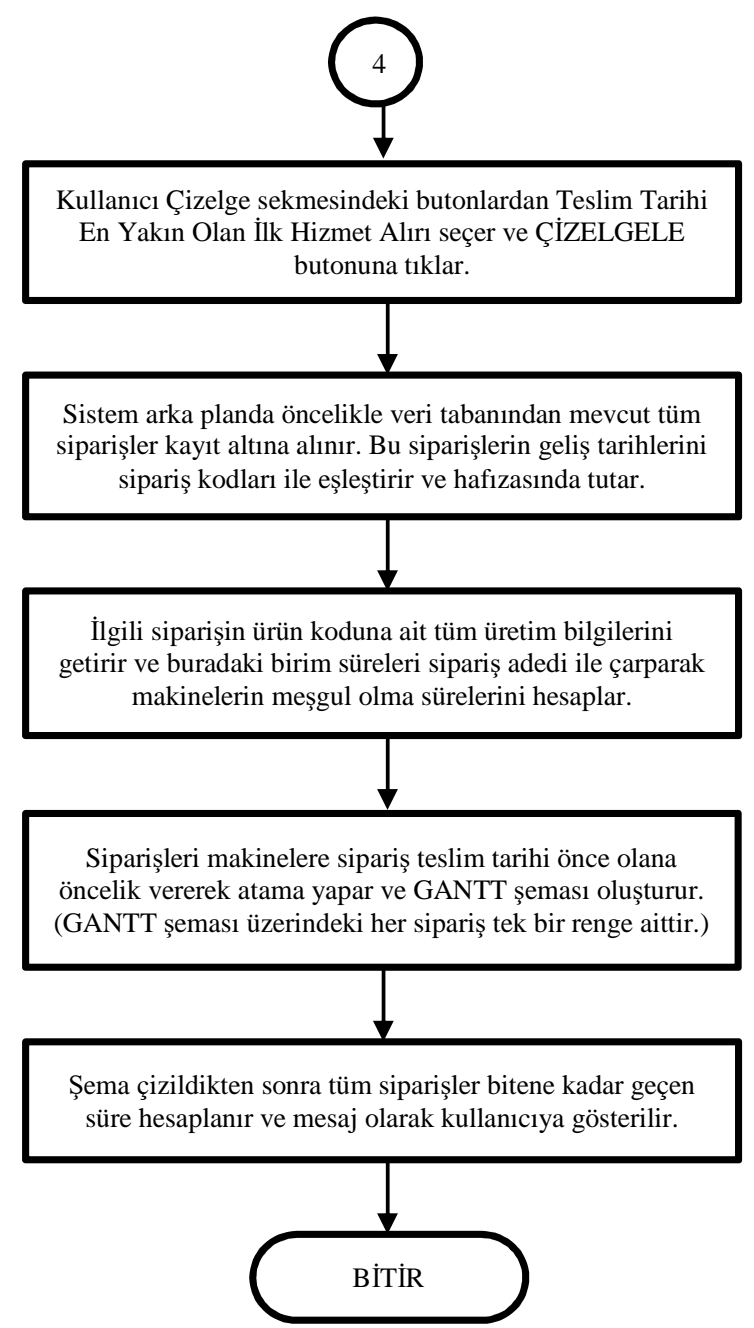

Şekil 16. Teslim tarihi en yakın olan ilk hizmet alır kuralının program içerisindeki döngüsü

\section{UYGULAMA/BULGULAR}

Bu bölümde yazılımı yapılmış olan çizelgeleme programı uygulaması sunulmuş ve elde edilen bulgular paylaşılmıştır.

Uygulama için seçilen firmadan toplanan veriler veri tabanı bölümü ile kayıt altına alınmıştır. Farklı öncelik sıralamaları ile Gantt diyagramları oluşturulmuş ve mevcut siparişlerin seçilen yönteme göre ne şekilde makinelere atama yapılması gerektiği gösterilmiştir. Son siparişin son işleminin bittiği an kayıt altına alınarak siparişlerin bitmesi için gerekli olan toplam süre hesapları incelenmiştir. Şekil 17'de ilk giren ilk hizmet alır yöntemine göre Gantt diyagramı çizelgesi gösterilmiştir. 


\begin{tabular}{|c|c|c|}
\hline & $\begin{array}{l}\text { BŞEÜ Fen Bilimleri Dergisi } \\
7(1), 421-443,2020\end{array}$ & $\begin{array}{r}\text { BSEU Journal of Science } \\
\text { DOI: } 10.35193 / \text { bseufbd.589585 }\end{array}$ \\
\hline & & 58-7575 (http://dergipark.gov.tr/bseufbd) \\
\hline
\end{tabular}

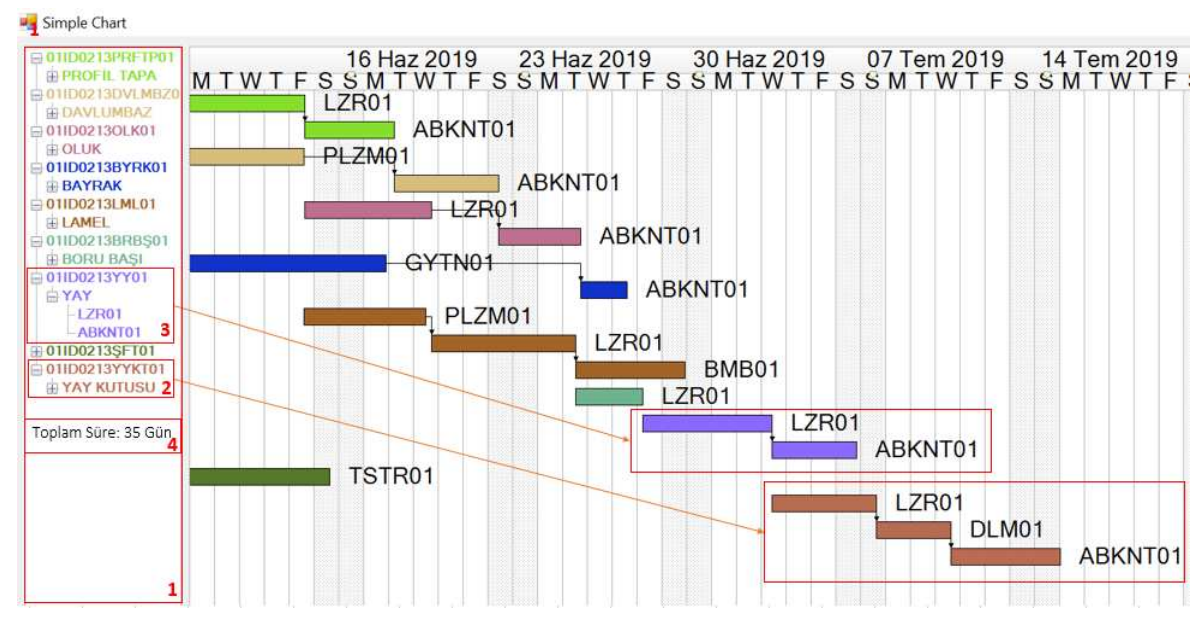

Şekil 17. İlk giren ilk hizmet alır yöntemi ile çizelgeleme

İlk giren ilk hizmet alır yöntemine göre Gantt diyagramı gösteriminde 1 numaralı bölüm mevcut sipariş listesini göstermektedir. Bu listede her sipariş farklı renk ile gösterilmektedir. Böylece diyagram üzerinde hangi blokun hangi siparişe ait olduğunun anlaşılması kolaylaştırılmıştır. Siparişlerin hangi ürünü içerdiği ve o ürünün üretim aşamaları 2 ve 3 numaralı bölümlerde de gösterildiği üzere artı ve aksi bölümlerinden sipariş kodları genişletilerek incelenebilir. Gantt diyagramı oluşturulduktan sonra mevcut tüm siparişlerin bitmesi için ne kadar süreye ihtiyaç duyulduğu hesaplanılarak 4 numaralı bölümde gösterilmektedir.

Şekil 18'de teslim tarihi en yakın olan ilk hizmet alır yöntemine göre Gantt diyagramı çizelgesi gösterilmiştir.

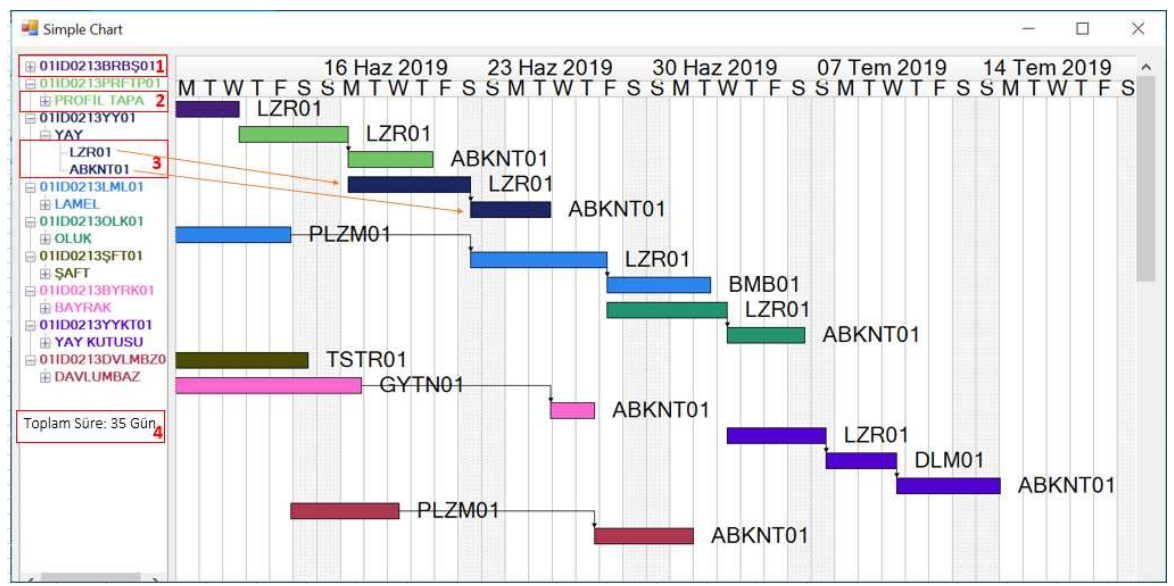

Şekil 18. Teslim tarihi en yakın olan ilk hizmet alır yöntemi ile çizelgeleme

Teslim tarihi en yakın olan ilk hizmet alır yöntemine göre Gantt diyagramı gösteriminde 1 numaralı bölüm sipariş kodudur. Bu kod müşteri ID numarası ve ürün ID numarasını bünyesinde bulundurur. Bu nedenle bir sipariş koduna bakıldığında hangi müşterinin siparişi olduğu ve hangi ürünü sipariş ettiği kolaylıkla anlaşılır. 2 numaralı bölümde sipariş kodu genişletilerek hangi ürünün sipariş edildiği görülmektedir. 3 numaralı bölümden herhangi bir ürünün üretilmesi için sırası ile hangi üretim merkezlerine uğraması gerektiği incelenebilir. 4 numaralı bölümde ise teslim tarihi en yakın olan ilk hizmet alır yöntemine göre çizelgeleme yapıldığında mevcut tüm siparişlerin üretilmesi için ne kadar süreye ihtiyaç duyulduğu görülmektedir. 


\begin{tabular}{|c|c|c|}
\hline & $\begin{array}{l}\text { BŞEÜ Fen Bilimleri Dergisi } \\
7(1), 421-443,2020\end{array}$ & $\begin{array}{r}\text { BSEU Journal of Science } \\
\text { DOI: } 10.35193 / \text { bseufbd.589585 }\end{array}$ \\
\hline ü & & 88-7575 (http://dergipark.gov.tr/bseufbd) \\
\hline
\end{tabular}

Şekil 19'da işlem süresi en uzun olan ilk hizmet alır yöntemine göre, Şekil 20'de ise işlem süresi en kısa olan ilk hizmet alır yöntemine göre Gantt diyagramı çizelgelemesi gösterilmektedir.

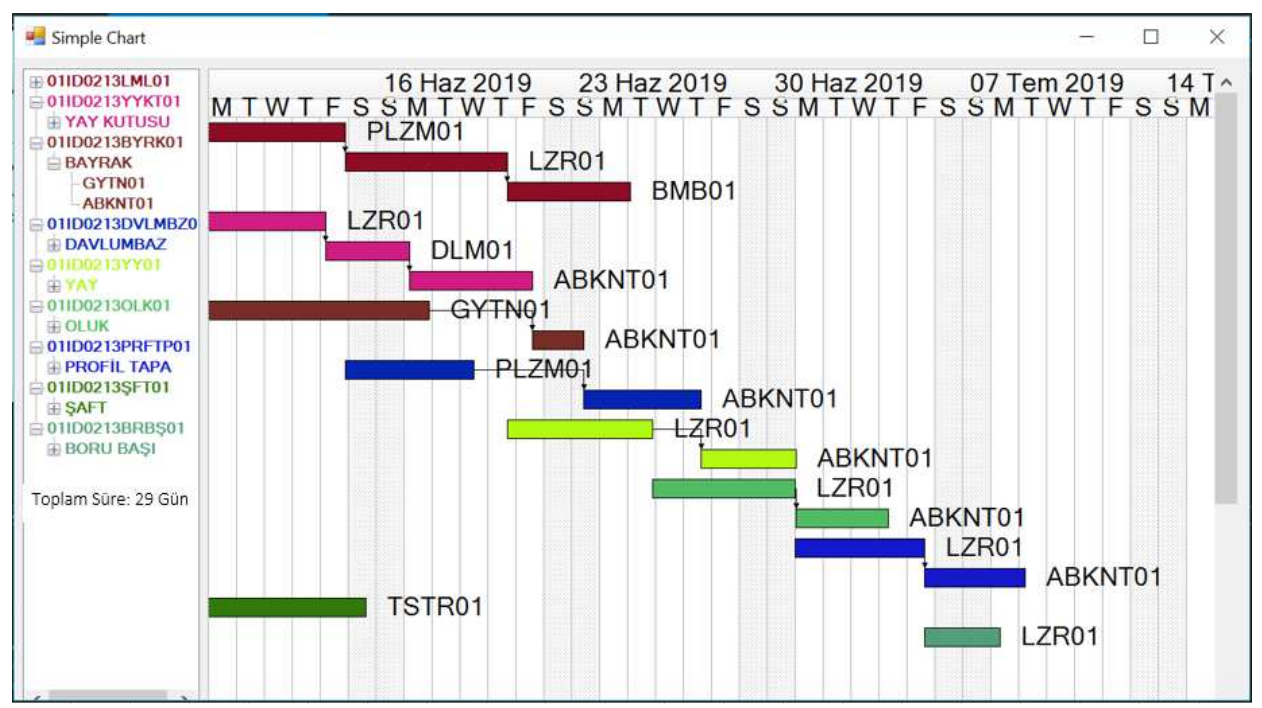

Şekil 19. İşlem süresi en uzun olan ilk hizmet alır yöntemi ile çizelgeleme

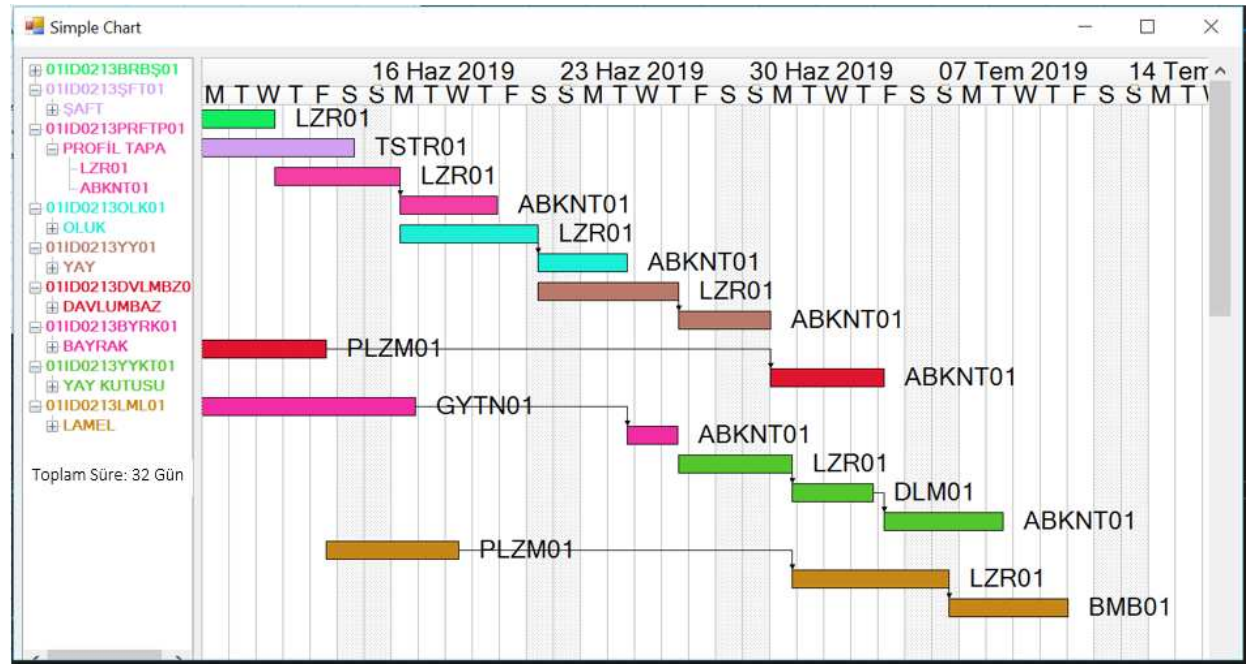

Şekil 20. İşlem süresi en kısa olan ilk hizmet alır yöntemi ile çizelgeleme

Kepenk üretimi yapan firmalara yarı mamul tedariki sağlayan firma için mevcut siparişlerin çizelgelemesi yapılmıştır. Dört farklı yönteme göre oluşturulan Gantt diyagramları sonucunda toplam süreler hesaplanmıştır. Firmanın en kısa sürede tüm siparişlerini üreterek müşteri memnuniyeti sağlaması amaçlanmıştır. Oluşturulan Gantt diyagramlarında toplam süreleri; ilk giren ilk hizmet alır yönteminde 35 gün, teslim tarihi en yakın olan ilk hizmet alır yönteminde 35 gün, işlem süresi en uzun olan ilk hizmet alır yönteminde 29 gün ve işlem süresi en kısa olan ilk hizmet alır yönteminde 32 gün olarak hesaplanmıştır. 


\section{SONUÇ}

Çizelgeleme problemleri karmaşık problemlerdir. Bu nedenle firmalar genellikle bir öncelik kuralını benimsemiş ve sürekli bu sisteme göre çalışmalarını gerçekleştirmektedir. Teknolojinin gelişmesi ile firmalar artık daha esnek çalışma koşullarına sahip olmaktadır. Çizelgeleme problemleri bu esnekliğe bir nevi engel olmaktadır. Çalışma sonucunda geliştirilen sistem sayesinde firmalar farklı öncelik kuralarının hesabını kolayca yapabilecek ve en uygun sonucu veren sistemi rahatlıkla seçebilecektir.

Çalışmanın uygulandığı firmada, çizelgeleme işleminin zor olması nedeniyle firma ilk giren ilk hizmet alır yöntemini kabul görmüş ve makine atamalarını her zaman bu yönteme göre gerçekleştirmekteydi. Geliştirilen program sayesinde dört farklı yönteme göre kıyaslama yaparak en uygun yöntemin seçilmesi ve ona göre makine atamalarının yapılması sağlanmıştır. Uygulama da verilen siparişler için en uygun makine atamalarının, işlem süresi en uzun olan ilk hizmet alır yöntemine göre yapılması gerektiğine karar verilmiştir. Böylelikle 35 günde yapılan işlem 29 güne düşürülmüştür.

\section{KAYNAKLAR}

[1] Aydemir, E., 2009. Atölye Tipi Çizelgeleme Problemlerinin Öncelik Kuralı Tabanlı Genetik Algoritma Yaklaşımıla Simülasyon Destekli Optimizasyonu. Süleyman Demirel Üniversitesi, Yüksek Lisans Tezi, Isparta.

[2] Sarıkaya, B., 2005. Otomotiv Yan Sanayinde Bir Üretim Çizelgeleme Probleminin İncelenmesi. Çukurova Üniversitesi, Yüksek Lisans Tezi, Adana.

[3] Candan, G., 2010. Esnek Üretim Çizelgeleme Probleminin Genetik Algoritma ve Bulanık Mantık Yöntemleri İle Çözülmesi. Sakarya Üniversitesi, Yüksek Lisans Tezi, Sakarya.

[4] Altındaş, M., 2011, Üretim Çizelgeleme ve Bir Uygulama. Bozok Üniversitesi, Yüksek Lisans Tezi, Yozgat.

[5] Doğan, N., 2013. Sıralamaya Bağımlı Hazırlı Sürelerinin Olduğu Permütasyonlu Akış Tipi Üretim Çizelgeleme Problemi İçin Bir NSGA-II Algoritması. Eskişehir Osmangazi Üniversitesi, Yüksek Lisans Tezi, Eskişehir.

[6] Eren, T., Güner, E., Tek ve Paralel Makinalı Problemlerde Çok Ölçütlü Çizelgeleme Problemleri İçin Bir Literatür Taraması

[7] Brucker, P. and Schile, R. (1990). Job-shop scheduling with multi-purpose machines. Journal on Computing, 45(4), 369-375.

[8] Paulli, J. 1995. A hierarchical approach for the FMS scheduling problem. European Journal of Operational Research, 86(1), 32-42.

[9] Brandimarte, P. 1993. Routing and scheduling in flexible job shops by tabu search, Annals. Operations Research, 41, 157-183.

[10] Mastrolilli, M. and Gambardella, LM. 1996. Effective neighbourhood functions for the flexible job shop problem. Journal of Scheduling, 3, 3-20

[11] Bagheri, A., Zandieh, M., Mahdavi, I. and Yazdani, M. (2010). An artificial immune algorithm for the flexible job-shop scheduling problem. Future Generation Computer Systems, 26, 533-541.

[12] Kacem, I., Hammadi, S. and Borne, P. (2002). Approach by localization and multiobjective evolutionary optimization for flexible job-shop scheduling problems. IEEE Transactions on Systems Man, and Cybernetics, 2002(a), Part C, 32, 1-13.

[13] Pinedo, M.L. 2008. Scheduling Theory Algorithms and Systems, USA: Springer. 


\begin{tabular}{|c|c|c|}
\hline & $\begin{array}{l}\text { BŞEÜ Fen Bilimleri Dergisi } \\
7(1), 421-443,2020\end{array}$ & $\begin{array}{l}\text { BSEU Journal of Science } \\
\text { DOI: } 10.35193 / \text { bseufbd } .589585\end{array}$ \\
\hline $\begin{array}{l}\text { BiLECEIK SEYHEDEBALL } \\
\text { UNIVERSITES }\end{array}$ & & 58-7575 (http://dergipark.gov.tr/bseufbd) \\
\hline
\end{tabular}

[14] Büyüksünetçi, A., 2006. Tepkin Çizelgeleme Yaklaşımının Akış Tipi Atölye Ortamında Etkinliğinin Analizi. Yüksek Lisans Tezi, Osmangazi Üniversitesi, Eskişehir.

[15] Tekbaş, H., 2011. Esnek sipariş tipi Üretim Sistemlerinde Müşteri Siparişlerinin Çizelgelenmesi. Doktora Tezi, İstanbul Teknik Üniversitesi, İstanbul. 